\title{
Toxicity of $\mathrm{Ag}, \mathrm{CuO}$ and $\mathrm{ZnO}$ nanoparticles to selected environmentally relevant test organisms and mammalian cells in vitro: a critical review
}

\author{
Olesja Bondarenko $\cdot$ Katre Juganson • \\ Angela Ivask · Kaja Kasemets · Monika Mortimer • \\ Anne Kahru
}

Received: 9 April 2013/Accepted: 8 May 2013/Published online: 1 June 2013

(c) The Author(s) 2013. This article is published with open access at Springerlink.com

\begin{abstract}
Nanoparticles (NPs) of copper oxide (CuO), zinc oxide $(\mathrm{ZnO})$ and especially nanosilver are intentionally used to fight the undesirable growth of bacteria, fungi and algae. Release of these NPs from consumer and household products into waste streams and further into the environment may, however, pose threat to the 'non-target' organisms, such as natural microbes and aquatic organisms. This review summarizes the recent research on (eco)toxicity of silver $(\mathrm{Ag}), \mathrm{CuO}$ and $\mathrm{ZnO}$ NPs. Organism-wise it focuses on key test species used for the analysis of ecotoxicological hazard. For comparison, the toxic effects of studied NPs toward mammalian cells in vitro were addressed. Altogether $317 \mathrm{~L}(\mathrm{E}) \mathrm{C} 50$ or minimal inhibitory concentrations (MIC) values were obtained for algae, crustaceans, fish, bacteria, yeast, nematodes, protozoa and mammalian cell lines. As a rule, crustaceans, algae and fish
\end{abstract}

Olesja Bondarenko and Katre Juganson have contributed equally to this work.

Electronic supplementary material The online version of this article (doi:10.1007/s00204-013-1079-4) contains supplementary material, which is available to authorized users.

O. Bondarenko - K. Juganson - A. Ivask · K. Kasemets .

M. Mortimer · A. Kahru $(\square)$

Laboratory of Environmental Toxicology, National Institute

of Chemical Physics and Biophysics, Akadeemia tee 23,

12618 Tallinn, Estonia

e-mail: anne.kahru@kbfi.ee

K. Juganson

Department of Chemistry, Tallinn University of Technology,

Ehitajate tee 5, 19086 Tallinn, Estonia

M. Mortimer

Aquatic Biogeochemistry and Ecotoxicology, Institute F.-A. Forel, Faculty of Sciences, University of Geneva, 10 route de Suisse, 1290 Versoix, Switzerland proved most sensitive to the studied NPs. The median $\mathrm{L}(\mathrm{E}) \mathrm{C} 50$ values of $\mathrm{Ag} \mathrm{NPs}, \mathrm{CuO}$ NPs and $\mathrm{ZnO} \mathrm{NPs}(\mathrm{mg} / \mathrm{L})$ were $0.01,2.1$ and 2.3 for crustaceans; $0.36,2.8$ and 0.08 for algae; and 1.36, 100 and 3.0 for fish, respectively. Surprisingly, the NPs were less toxic to bacteria than to aquatic organisms: the median MIC values for bacteria were 7.1, 200 and $500 \mathrm{mg} / \mathrm{L}$ for $\mathrm{Ag}, \mathrm{CuO}$ and $\mathrm{ZnO} \mathrm{NPs}$, respectively. In comparison, the respective median $\mathrm{L}(\mathrm{E}) \mathrm{C} 50$ values for mammalian cells were $11.3,25$ and $43 \mathrm{mg} / \mathrm{L}$. Thus, the toxic range of all the three metalcontaining NPs to target- and non-target organisms overlaps, indicating that the leaching of biocidal NPs from consumer products should be addressed.

Keywords Risk assessment · In vitro toxicology · Antimicrobials · Mechanism of action · REACH - QSARs

\section{Introduction}

Nanoindustry is one of the fastest growing industries in the history of mankind and has been referred to as the next industrial revolution (Lux Research 2008). The first national nanotechnology program-the National Nanotechnology Initiative-was launched in USA in 2000. Since then, more than 60 nations have established similar programs. In 2010, worldwide annual public and private sector funding for nanotechnologies was 17.8 billion dollars in total (Sargent 2012). As a result, the global socioeconomic value of nanotechnologies is steadily increasing, and currently, nanoscale particles have significant impacts on almost all industries and all areas of society.

According to the recent review issued by the European Commission (2013), nanomaterial is defined as 'a natural, incidental or manufactured material containing particles, in 
an unbound state or as an aggregate or as an agglomerate and where, for $50 \%$ or more of the particles in the number size distribution, one or more external dimensions is in the size range $1-100 \mathrm{~nm}$. In specific cases and where warranted by concerns for the environment, health, safety or competitiveness the number size distribution threshold of $50 \%$ may be replaced by a threshold between 1 and $50 \%$.' In scientific literature engineered (or manufactured or synthetic or man-made) nanoparticles (NPs) are usually defined as particles with at least one dimension between 1 and $100 \mathrm{~nm}$.

At nanoscale materials have different or enhanced properties compared with their conventional 'bulk' (microsize) counterparts, due to an increased relative surface area that translates into higher reactivity ( $\mathrm{Nel}$ et al. 2006). While in bulk materials the surface atoms constitute only a few percent of the total number of atoms, in NPs most of the atoms lay close to or at the surface (Casals et al. 2012). There is increasing evidence that the unique desired physico-chemical properties of NPs, which make nanomaterials more efficient in industrial applications, render these materials also more harmful to living organisms. Due to increasing production volumes of NPs and growing likelihood of occupational and environmental exposure to nanomaterials, the legislative bodies in both EU and USA have currently focused their activities on assessing health and environmental risks of nanotechnology.

As shown in Fig. 1, this review aims to provide a critical summary of recent scientific literature on potential hazardous effects of three types of engineered metal-containing NPs-zinc oxide $(\mathrm{ZnO})$, copper oxide $(\mathrm{CuO})$ and silver (Ag). All these compounds (either in the bulk or nanoform) have been historically used as biocides, that is, for avoiding or stopping the growth of microorganisms and algae (Kahru and Dubourguier 2010). Therefore, similarly to pesticides, these nanomaterials should be monitored for their toxic action also toward non-target species, including humans. In the context of the current review, 'target organism' is defined as an organism for which the biocidal NPs were designed for (e.g., bacteria and fungi as target organisms of all three NPs and algae as target organisms of $\mathrm{CuO}$ and $\mathrm{Ag}$ NPs) and 'non-target organism' is an organism which will be exposed to NPs after their incidental release into the environment. To gain a better understanding whether the accidental release of metal-containing NPs may pose a threat to non-target species, we collected toxicity data on these NPs for algae, crustaceans, fish, bacteria, yeast, nematodes, protozoa and mammalian cell lines and compared the toxicity values of NPs to target- and non-target organisms. In addition, we analyzed the collected data with respect to the correlation between the dissolution, size and coating of NPs and their toxicity to different organism groups. Finally, we classified the studied NPs into different hazard categories. However, the proposed hazard categories are rather general and could only be applied for the initial hazard identification. For complete risk assessment, further data on realistic environmental exposure scenarios for these NPs are required. Also, in case of mammalian cell lines, we do not discuss the transferability of collected in vitro data to in vivo situation.

\section{Production and application of $\mathrm{Ag}, \mathrm{CuO}$ and $\mathrm{ZnO}$ (nano)particles}

Estimated global production of NPs is shown in Fig. 2a (adapted from Piccinno et al. 2012). Although $\mathrm{SiO}_{2} \mathrm{NPs}_{\mathrm{Na}}$ produced at the highest production volume (Fig. 2), Ag NPs are the ones most used in consumer products. According to the Woodrow Wilson Database (Wilson 2012), there were more than 1,300 nanotechnological consumer products on the market in March 2011, and 313 of them contained nanosilver. In consumer products, NPs are either added to the bulk material to reinforce the physical properties of the material or applied on the surface of the product to provide enhanced surface features such as scratch resistance, water repellency, reflectivity and photo activity. As the number of published articles can be considered as an early indicator of the future use of NPs, ISI Web of Science (ISI WoS) was used to gather data on the current and potential applications of $\mathrm{Ag}$, $\mathrm{ZnO}$ and $\mathrm{CuO}$ NPs (Table S1 and in Fig. 2). The analysis of the collected data showed that the majority of articles concerned the applications of Ag NPs (7,699 papers, $59 \%)$, followed by $\mathrm{ZnO}(4,640$ papers, $36 \%)$ and finally $\mathrm{CuO}$ NPs (690 papers, $5 \%$ ). Interestingly, the most prominent application area of all these three NPs was sensors, sensing devices and catalysis (Fig. 2b-d). Moreover, as silver is the best conductor among the metals (Ren et al. 2005) and Ag NPs have favorable chemical and physical properties such as biocompatibility, unique electronic and catalytic properties, Ag NP-based electrochemical (bio)sensing systems have been developed (Lian et al. 2013) that enable enhancing electron transfer between biomolecules (e.g., proteins) and electrode surfaces. As expected, a considerable share (19\%) of all the fields of application of Ag NPs concerned antimicrobial usage. In case of $\mathrm{CuO}$ NPs and $\mathrm{ZnO}$ NPs, this share was much lower, 4 and $2.6 \%$, respectively.

\section{Ag nanoparticles}

Silver has been used to fight infections as far back as the days of ancient Greece and Egypt. In World War I, before the advent of antibiotics, silver compounds were used to prevent and treat infections. Currently, Ag NPs are the most widely commercialized NPs that are used as antimicrobials in various consumer products ranging from cosmetics, 
Fig. 1 Schematic representation of the scope of the current review

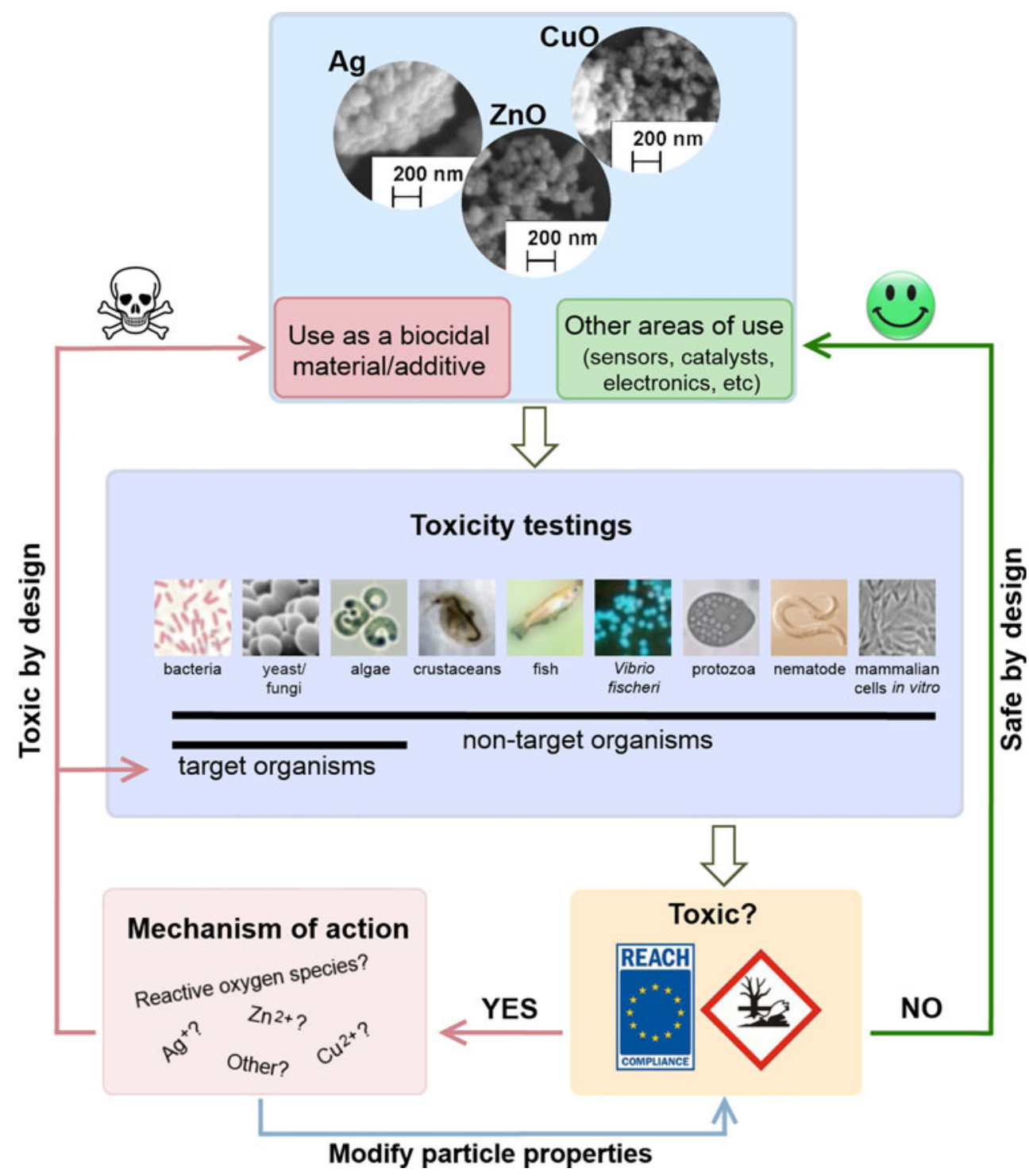

clothing, shoes, detergents, dietary supplements to surface coatings in respirators, water filters, phones, laptops, toys and commercial home water purification systems such as Aquapure, Kinetico and QSI-Nano (Bystrzejewska-Piotrowska et al. 2009; Marambio-Jones and Hoek 2010; Cerkez et al. 2012). In addition to antibacterial, antiviral and antifungal properties (for the review and references therein, see Ivask et al. 2012), nanosilver has also been shown to facilitate wound healing (Nair and Laurencin 2007). Estimated global annual production of Ag NPs is $\sim 55$ tons (a median value; Piccinno et al. 2012; Fig. 2a).

$\mathrm{ZnO}$ nanoparticles

According to different sources, the worldwide annual production of ZnO NPs is estimated to be between 550 (Piccinno et al. 2012; Fig. 2d) and 33,400 tons (Research and Markets 2012). Thus, among metal-containing NPs, ZnO NPs have the third highest global production volume after $\mathrm{SiO}_{2}$ and $\mathrm{TiO}_{2}$ NPs (5,500 and 3,000 tons annually, respectively) (Piccinno et al. 2012; Fig. 2a). ZnO NPs are mostly used as a UV light scattering additive in cosmetics such as sunscreens, toothpastes and beauty products (Serpone et al. 2007). ZnO NPs are widely used in rubber manufacture, production of solar cells and LCDs, pigments (as a whitener), chemical fibers, electronics and textiles (Dastjerdi and Montazer 2010; Song et al. 2010). In addition, $\mathrm{ZnO}$ is an essential ingredient in almost all types of antifouling paints (IPPIC 2012), and recently bulk $\mathrm{ZnO}$ has been increasingly replaced by $\mathrm{ZnO}$ NPs because of their enhanced antibacterial properties (Padmavathy and Vijayaraghavan 2008).

$\mathrm{CuO}$ nanoparticles

In contrast to $\mathrm{Ag}$ and $\mathrm{ZnO} \mathrm{NPs}$, we were not able to retrieve data on the current production volumes of $\mathrm{CuO}$ 
Fig. 2 a Annual production volumes of nanomaterials (data are adapted from Piccinno et al. 2012). b-d Fields of application of $\mathrm{Ag}(\mathbf{b}), \mathrm{CuO}$ (c) and $\mathrm{ZnO}$ (d) nanoparticles based on the publications indexed by Thomson Reuters ISI Web of Science. Search was done in March 2013. The following search terms were used: 'silver' OR 'CuO' OR 'ZnO' AND 'nano*' AND 'application category' (indicated in the figure). Numbers next to each application category indicate the number of articles retrieved and their respective percent share.

The numerical data are presented in Supplementary Table S1 a annual production of NPs

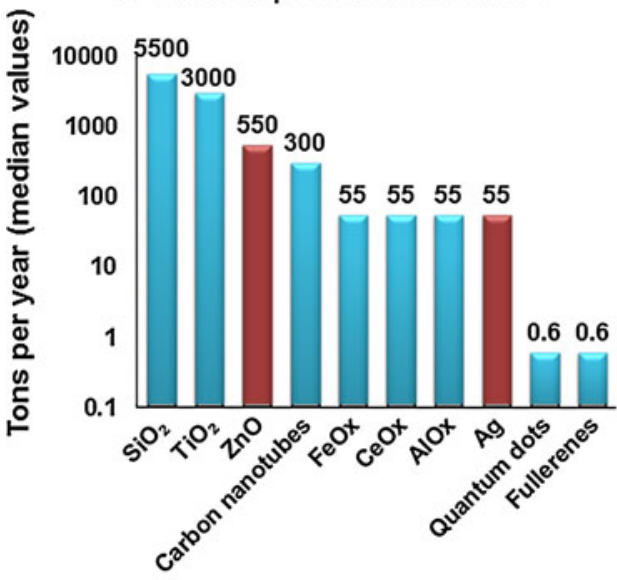

c ISI WoS data on CuO NPs

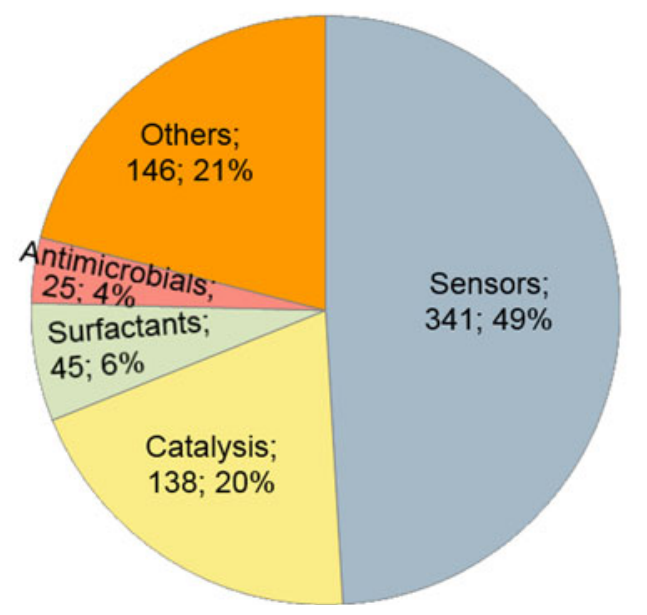

b ISI WoS data on Ag NPs

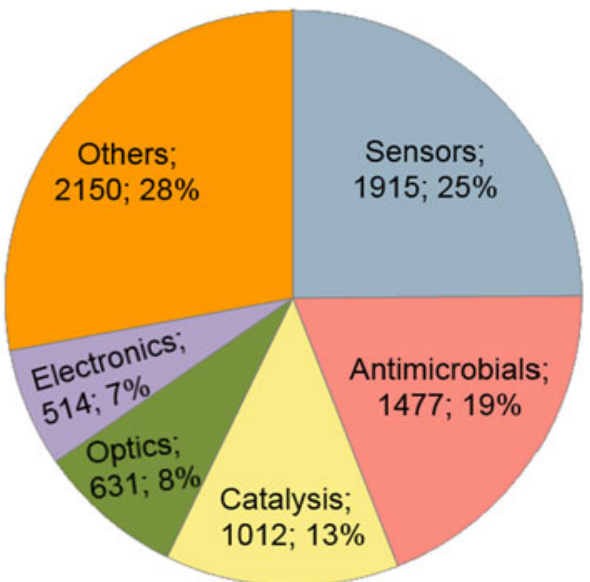

d ISI WoS data on ZnO NPs

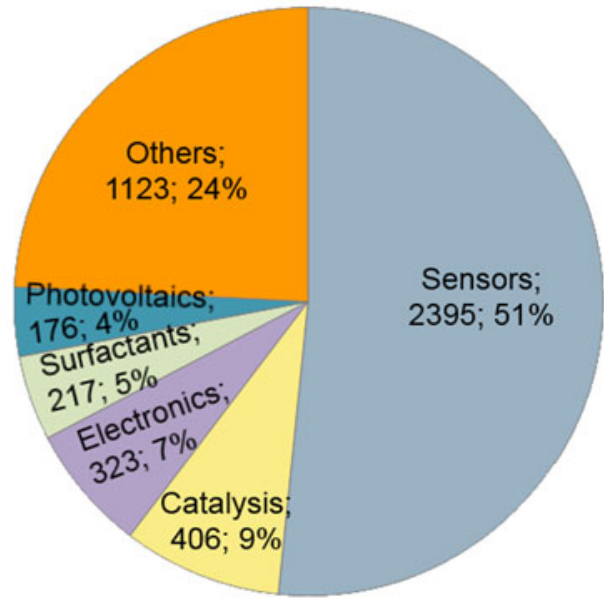

NPs. As these NPs are used in lower quantities and compared to other NPs the potential hazardous effects of $\mathrm{CuO}$ NPs are poorly studied (Kahru and Savolainen 2010), it is reasonable to conclude that they are also manufactured in lower amounts compared to other NPs. As reflected by Fig. 2c, the most important and unique application area of $\mathrm{CuO}$ NPs is electronics and technology (semiconductors, electronic chips, heat transfer nanofluids), as $\mathrm{CuO}$ has excellent thermophysical properties (Ebrahimnia-Bajestan et al. 2011). Also other applications such as gas sensors ( $\mathrm{Li}$ et al. 2007), catalytic processes (Carnes and Klabunde 2003), solar cells and lithium batteries (Guo et al. 2009; Sau et al. 2010) have been suggested for CuO NPs. CuO NPs have been shown to inhibit the growth of microorganisms and exert antiviral properties (Borkow and Gabbay 2004; Gabbay et al. 2006). For these reasons, CuO NPs have been used in face masks, wound dressings and socks to give them biocidal properties (Borkow et al. 2009, 2010a, b).

\section{The need for toxicity data on $\mathrm{ZnO}, \mathrm{CuO}$ and $\mathrm{Ag}$ (nano)particles}

Toxicity data and data quality gaps for nanoparticles

The scientific information on potential harmful effects of NPs severely lags behind the development of nanotechnologies (Shvedova et al. 2010; Kahru and Ivask 2013). In addition, the available nanotoxicity data are inconsistent because experimental approaches vary from article to article making it impossible to compare results (Schrurs and Lison 2012). To overcome these problems, nanotoxicology community has recently started a discussion about the implementation of general guidelines for nanotoxicology research and establishment of common parameters that should be addressed in all nanotoxicological articles (Nature Nanotech Editorial 2012). 
Legislation gaps for nanoparticles

Currently, the production and use of nanoparticle-containing products is not internationally regulated by any distinct safety regulation (EC 2008). Compared to bulk materials, NPs have unique physico-chemical properties such as higher stability in the aquatic environment (Fig. 3b), decreased size (Fig. 3c) and increased specific surface area (SSA), and thus enhanced reactivity. These properties make NPs more efficient and interesting for different industrial applications but at the same time make them more harmful to living organisms. Thus, theoretically a special guidance should be considered for NPs. Yet, as NPs are chemically identical to their bulk counterparts and thus have the same CAS number (Fig. 3a), they are not recognized by industry as a new class of chemicals. As a result, the production and use of metal-containing NPs are subject to analogous regulation as the conventional bulk chemical compounds regulated in Europe by EU chemical safety policy REACH (Registration, Evaluation, Authorisation and Restriction of Chemicals). The REACH regulation states that when chemicals/NPs are produced in a volume of more than one ton per year and sold at the European market, they must be characterized for their potential impact on aquatic ecosystems (European Parliament 2006). The data provided by the producer/importer should include short-term (48 h) toxicity testing on crustaceans (preferred species Daphnia magna, OECD 2004) and $72 \mathrm{~h}$ growth inhibition of aquatic plants (preferably algae, OECD 2011). In addition, short-term (96 h) toxicity testing on fish (OECD 1992) is required at the next annual tonnage level ( $>10$ tons per year). As shown in Crane et al.
(2008), Kahru et al. (2008) and Kahru and Dubourguier (2010), the types of test species and biological endpoints used within standard environmental hazard assessment frameworks are generally appropriate also for nanoecotoxicological purposes. The additional specific requirements for NP studies are the dispersion conditions and characterization of the particles in the test environment as well as careful consideration of test conditions for potential artifacts that can arise due to the color of NPs or their sorptive properties (Handy et al. 2012; Schrurs and Lison 2012; Bayat et al. 2013). Analogously to the rest of the chemical compounds, NPs are classified with respect to their environmental toxicity according to the response of the most sensitive of the three test organisms: algae, crustaceans and fish (European Union 2011).

\section{Specific physico-chemical properties of metal- containing nanoparticles}

In order to understand the mechanisms behind the toxicity of NPs, the physico-chemical properties of the particles should be thoroughly analyzed in relevant test environments. Recent review by Bandyopadhyay et al. (2012) gives an in-depth overview of the methods that can be applied to characterize NPs size, shape, crystal structure, aggregation, chemical composition, surface properties (surface charge, area, chemistry), solubility and porosity. Since detailed reviews about characterization of the NPs can be found elsewhere, the following paragraphs of this review focus on joint nominators and differences in the physico-chemical characteristics of $\mathrm{Ag}, \mathrm{CuO}$ and $\mathrm{ZnO}$ NPs.
Fig. 3 a Labels of bulk $\mathrm{CuO}$ and nanosized $\mathrm{CuO}$. Note the same CAS number. b $200 \mathrm{mg} / \mathrm{L}$ stock suspensions of $\mathrm{CuO}$. c TEM image of nano $\mathrm{CuO}$ and bulk $\mathrm{CuO}$. Note 43-fold difference in the SSAs of bulk $\mathrm{CuO}$ and nanosized $\mathrm{CuO}$
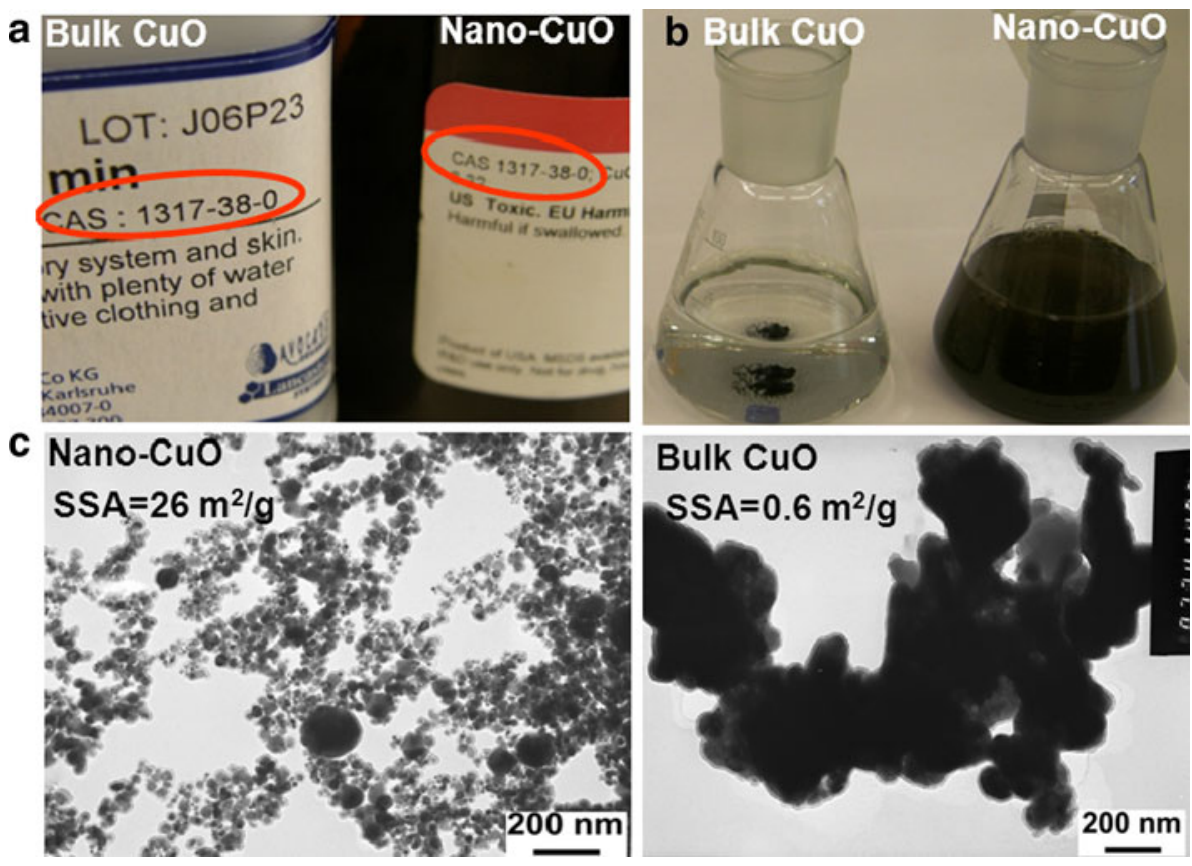
Joint nominators for $\mathrm{Ag}, \mathrm{CuO}$ and $\mathrm{ZnO}$ nanoparticles

Considering the joint nominators for $\mathrm{Ag}, \mathrm{CuO}$ and $\mathrm{ZnO}$ NPs, the first to notice is the metallic elemental composition of all the three selected particles. Secondly, all the three NPs are applied to fight the undesirable growth of microorganisms. Although among the three nanomaterials, silver NPs are used most widely as antimicrobials, also $\mathrm{CuO}$ and $\mathrm{ZnO}$ NPs have been successfully used as biocides (Fig. 2c-d). The third joint nominator for the three NPs is their negative surface charge, which results from oxygen atoms in $\mathrm{CuO}$ and $\mathrm{ZnO}$ (Xu et al. 2012). Though $\mathrm{Ag}$ NPs do not initially contain oxygen, the surface of metallic Ag NPs is oxidized under most environmental conditions (aerobic) and negatively charged hydroxo and oxo groups cause the negative surface charge of the particle (Levard et al. 2012). The fourth and toxicologically perhaps the most important joint property is that all the three NPs are soluble to some extent in aqueous media. We have previously shown that the solubility of $\mathrm{CuO}$ and $\mathrm{ZnO}$ NPs is the key issue in the toxicity of metal-containing (nano)particles and stressed that the solubility data reported as N/A (not available or not applicable) in Material Safety Data Sheet (MSDS) of $\mathrm{ZnO}$ and $\mathrm{CuO}$ NPs should be addressed (Aruoja et al. 2009; Ivask et al. 2010; Bondarenko et al. 2012). It has been also emphasized that aqueous solubility of NPs has to be incorporated into the environmental risk assessment models of NPs in addition to other key physico-chemical characteristics relevant to NPs (European Commission 2007). Solubility of NPs and the behavior of released metal ions, that is, the proportion of intact particles, metal ions and metal complexes, depend greatly on the properties of the test environment (for a review and references therein, see Casals et al. 2012). The most important parameters of the test environment are $\mathrm{pH}$, dissolved organic carbon content and water hardness (Wiench et al. 2009; Fabrega et al. 2011). For instance, the solubility of all the three selected particles is enhanced at more acidic pH (Dimkpa, et al. 2011; Fabrega et al. 2011; Levard et al. 2012; Ma et al. 2013). Also, the solubility of the aforementioned NPs depends on their interactions with organic material in the test environment (proteins, amino acids, natural organic matter, humic substances) that may coat and disperse NPs or complex metal ions. For example, reduced solubility and toxicity toward crustaceans has been observed in natural waters for Ag NPs (Gao et al. 2009) and CuO NPs (Blinova et al. 2010).

Figure 4 illustrates the behavior of NPs in various test environments: in all test media coated Ag NPs are remarkably more stable than the uncoated NPs. That is coherent with the results by Fabrega et al. (2011) showing that in high ionic strength suspensions uncoated
Ag NPs tend to precipitate and sediment within a few hours after the start of the toxicity assay. Also, $\mathrm{CuO}$ and $\mathrm{ZnO}$ NPs were remarkably unstable and tended to sediment. Figure 4 also shows that the agglomeration/sedimentation of $\mathrm{CuO}$ and $\mathrm{ZnO}$ was especially high in mineral media-media that are used for key regulatory ecotoxicological assays (crustaceans, algae) described above. In contrast, the components of the complex test media (defined here as the test environment with organic components) dispersed NPs and prevented their sedimentation. In addition, the complex media may promote dissolution of NPs (Käkinen et al. 2011; Kasemets et al. 2013).

In summary, as also underlined in the recent paper by Casals et al. (2012), it is extremely important to assess the physico-chemical properties of NPs in the media where the biological toxicity tests are performed. As dissolution is one of the main contributors to the toxicity of $\mathrm{Ag}, \mathrm{CuO}$ and $\mathrm{ZnO} \mathrm{NPs}$, in this review their toxicity is discussed in parallel with the toxic effects of the respective ions.

Differences between $\mathrm{Ag}, \mathrm{CuO}$ and $\mathrm{ZnO}$ nanoparticles

In addition to the above-described joint nominators, there are also differences between the three NPs selected for this study. To begin with, their chemical composition is different; thus, in similar particle size their toxicity is likely different (Sharifi et al. 2012). In addition, copper is a redox element having common valences of +2 or +1 . Thus, differently from zinc and silver, redox-active $\mathrm{Cu}$ ions may also be involved in electron-transfer processes. Third, the surface of $\mathrm{Ag}$ NPs but not $\mathrm{CuO}$ and $\mathrm{ZnO}$ NPs is frequently functionalized with different coatings, polyvinylpyrrolidone (PVP) and citrate being the most widely used. Last but not least, copper and zinc (but not silver) are necessary trace elements for almost all types of living cells, while silver has no known function in the living organisms (Sandstead 1995).

\section{Toxicity of $\mathrm{Ag}, \mathrm{CuO}$ and $\mathrm{ZnO}$ nanoparticles to target and non-target organisms}

The review by Crane et al. (2008) summarizes various OECD assays that can be applied for the toxicity testing of NPs. Assessment of the environmental hazard of NPs under REACH regulation requires that at least two OECD tests with algae (OECD201) and crustacean D. magna (OECD202) should be used. In this review, we collected, analyzed and summarized the toxicity data (including but not limited to the key OECD test species) from the published literature on $\mathrm{ZnO}, \mathrm{CuO}$ and $\mathrm{Ag}$ NPs. 


\section{Ag NPs (40-110 nm, uncoated) Ag NPs (2-30 nm, PVP-coated) CuO NPs (30 nm, uncoated) ZnO NPs (70 nm, uncoated)}

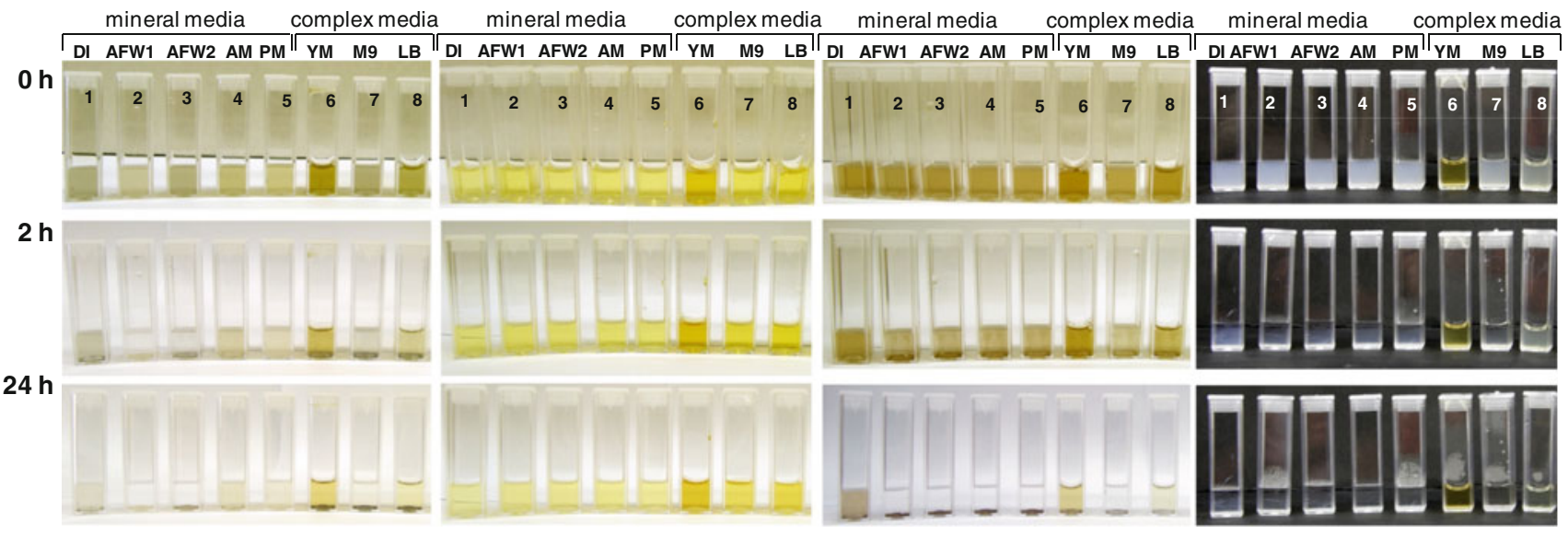

Fig. 4 Uncoated Ag (50 mg/L), PVP-coated Ag (50 mg/L), uncoated $\mathrm{CuO}(50 \mathrm{mg} / \mathrm{L})$ and $\mathrm{ZnO} \mathrm{NPs}(200 \mathrm{mg} / \mathrm{L})$ after 0,2 and $24 \mathrm{~h}$ incubation in different (eco)toxicological test environments: 1 deionized water; 2 artificial freshwater for the tests with Daphnia sp. (OECD 202); 3 AFW for Thamnocephalus sp. (Thamnotoxkit $\mathrm{F}^{\mathrm{TM}}$ 1995); 4 algal growth medium (OECD 201); 5 protozoan mineral test medium (Osterhout's); 6 yeast extract peptone dextrose medium; 7 bacterial M9 medium supplemented with $0.1 \%$ glucose and $0.5 \%$ amino acids; 8 bacterial LB medium containing tryptone and yeast extract. Detailed composition of test media is given in Käkinen et al. (2011)
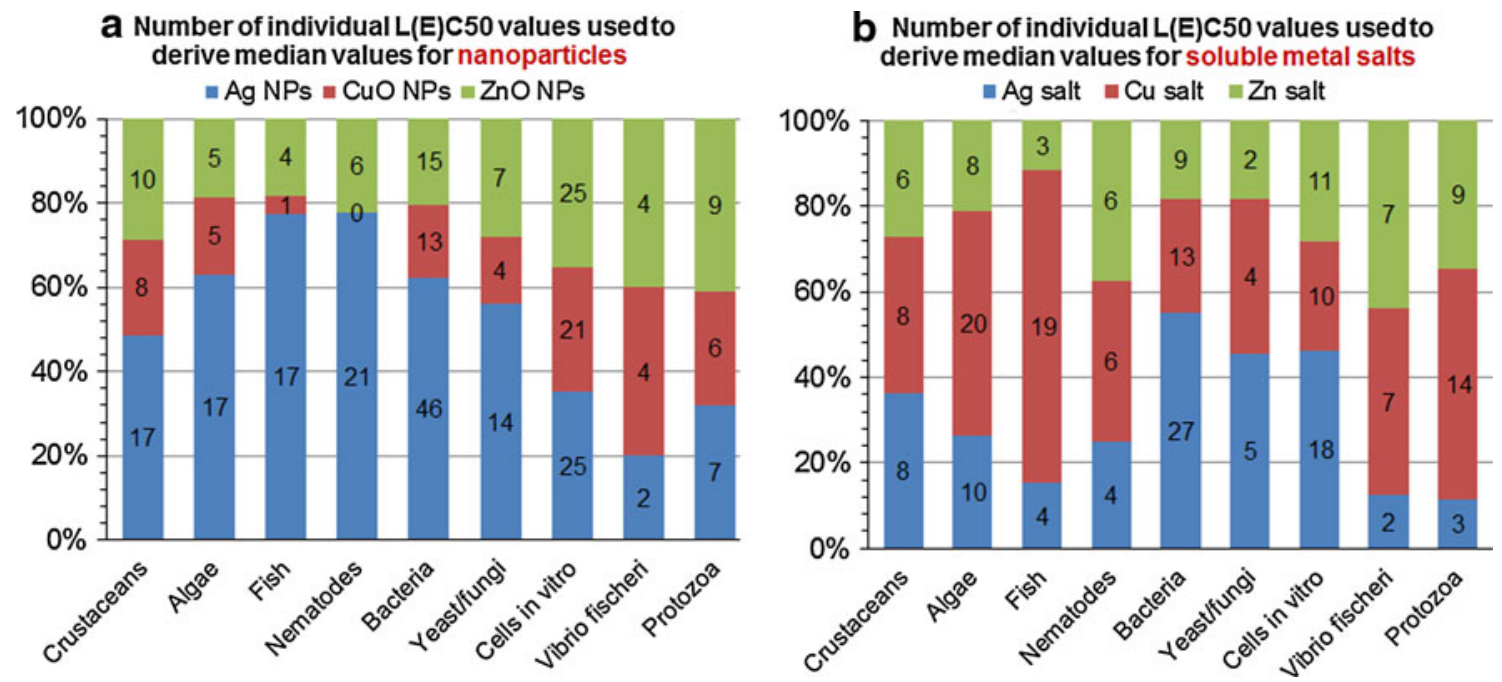

Fig. 5 Number and share of individual L(E)C50 or MIC values used to derive the median L(E)C50 or MIC for nanoparticles (a) and metal salts (b). Total number of individual values: 317

Characterization of retrieved toxicity data set

When collecting the toxicity data for $\mathrm{Ag}, \mathrm{CuO}$ and $\mathrm{ZnO}$ NPs, we relied on recent nano(eco)toxicological peerreviewed literature that preferably contained data not only on toxicity of NPs but also physico-chemical characteristics of the studied NPs prior to and during toxicity testing. Our goal was to find at least 10 quantitative toxicity values (EC50, LC50, MIC) per organism and NP type. In parallel, we collected toxicity data for metal ions to assess the impact of dissolution on toxicity of NPs. Organism-wise we focused on bacteria, crustaceans, algae, fish, nematodes, yeasts, protozoa as well as on mammalian cell lines.

Figure 5 shows the availability of the toxicity data in ISI WoS. As can be seen, relatively large amount of data was available on toxicity of Ag NPs, whereas less information was published on toxicity of $\mathrm{ZnO}$ NPs and the data on $\mathrm{CuO}$ were especially scarce. At the same time, there was a lot of data on the toxicity of both $\mathrm{Cu}$ and $\mathrm{Ag}$ ions, while less information was available on the toxicity of $\mathrm{Zn}$ ions.

Table S2 presents data on the test organisms that were used most often for determining the L(E)C50 and MIC values in the analyzed literature. As shown in Table S2, the 
Fig. 6 Toxicity of $\mathrm{CuO}, \mathrm{ZnO}$ and $\mathrm{Ag}$ nanoparticles to different organisms. Median $\mathrm{L}(\mathrm{E}) \mathrm{C} 50$ values for all other organisms except bacteria and MIC for bacteria \pm minimum and maximum values are presented. Different organisms/ cells are shown by respective pictograms and the number on the pictogram indicates the number of $\mathrm{L}(\mathrm{E}) \mathrm{C} 50$ values used to derive the median value. Note the logarithmic scale of $x$-axis and that $\mathrm{L}(\mathrm{E}) \mathrm{C} 50$ and $\mathrm{MIC}$ values of NPs reflect nominal concentrations. The classification to hazard categories is explained in Table 1
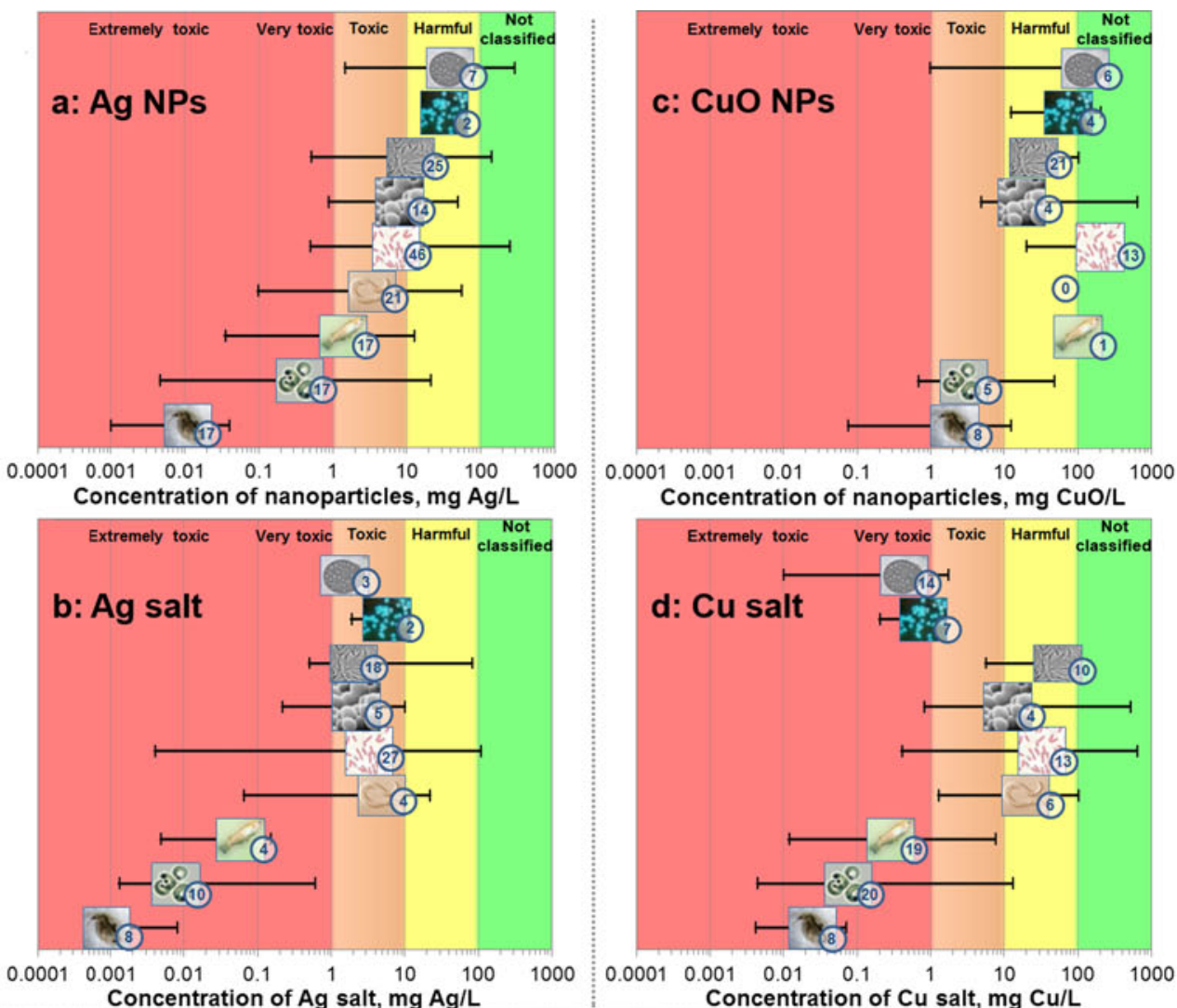

Concentration of nanoparticles, $\mathrm{mg} \mathrm{CuO/L}$
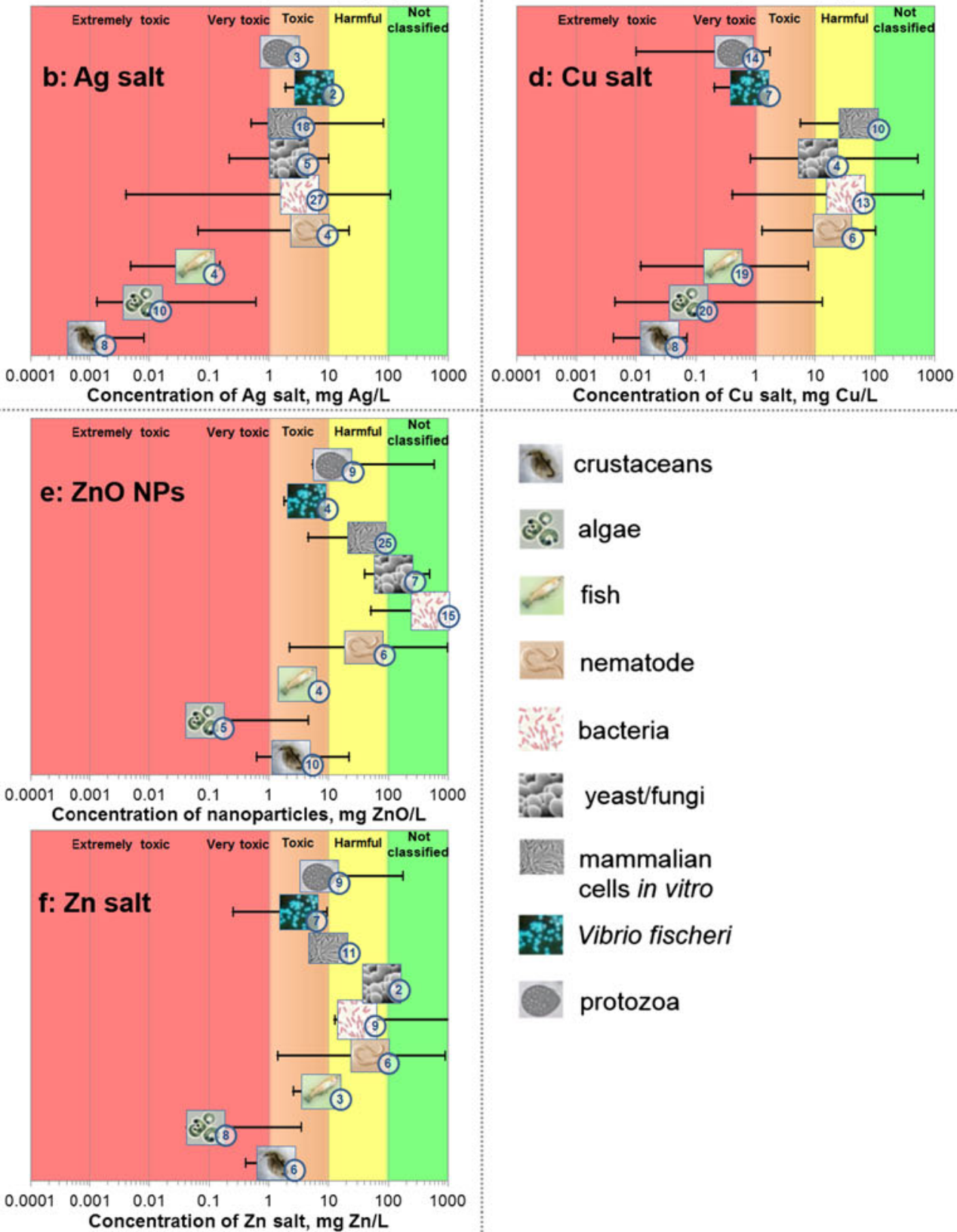

\section{crustaceans}

algae

fish

nematode

bacteria

yeast/fungi

mammalian

cells in vitro

Vibrio fischeri

protozoa 
Table 1 Median L(E)C50 values for all organisms except bacteria and median MIC for bacteria for Ag, $\mathrm{CuO}$ and $\mathrm{ZnO}$ nanoparticles (NPs) and the respective metal salts

\begin{tabular}{|c|c|c|c|c|c|c|}
\hline \multirow[t]{2}{*}{ Group of organisms } & \multicolumn{3}{|c|}{$\begin{array}{l}\text { Median } \mathrm{L}(\mathrm{E}) \mathrm{C} 50 \text { or } \mathrm{MIC} \text {, on compound } \\
\text { basis, } \mathrm{mg} / \mathrm{L} \text { (number of data)* }\end{array}$} & \multicolumn{3}{|c|}{$\begin{array}{l}\text { Median } \mathrm{L}(\mathrm{E}) \mathrm{C} 50 \text { or MIC, on metal basis, mg } \\
\text { metal/L (number of data)* }\end{array}$} \\
\hline & Ag NPs & $\mathrm{CuO}$ NPs & ZnO NPs & Ag salt & $\mathrm{Cu}$ salt & Zn salt \\
\hline Crustaceans & $0.01(17)$ & $2.1(8)$ & $2.3(10)$ & $0.00085(8)$ & $0.024(8)$ & $1.3(6)$ \\
\hline Algae & $0.36(17)$ & $2.8(5)$ & $0.08(5)$ & $0.0076(10)$ & $0.07(20)$ & $0.09(8)$ \\
\hline Fish & $1.36(17)$ & $100(1)$ & $3.0(4)$ & $0.058(4)$ & $0.28(19)$ & $7.5(3)$ \\
\hline Nematodes & $3.34(21)$ & $\begin{array}{l}\text { Not found } \\
(0)\end{array}$ & $39(6)$ & $4.8(4)$ & $19.4(6)$ & $49(6)$ \\
\hline Bacteria & $7.10(46)$ & $200(13)$ & $500(15)$ & $3.3(27)$ & $32(13)$ & $30(9)$ \\
\hline Yeast & $7.90(14)$ & $17(4)$ & $121(7)$ & $2.16(5)$ & $11.1(4)$ & $78(2)$ \\
\hline Mammalian cells in vitro & $11.3(25)$ & $25(21)$ & $43(25)$ & $2(18)$ & $53(10)$ & $9.8(11)$ \\
\hline$V \cdot$ fischeri $^{\mathrm{a}}$ & $32(2)$ & $73.6(4)$ & $4.3(4)$ & $5.7(2)$ & $0.78(7)$ & $3.2(7)$ \\
\hline Protozoa & $38(7)$ & $124(6)$ & $11.7(9)$ & $1.5(3)$ & $0.43(14)$ & $7(9)$ \\
\hline Lowest L(E)C50, MIC & 0.01 & 2.1 & 0.08 & 0.00085 & 0.024 & 0.09 \\
\hline Most sensitive organisms & Crustaceans & Crustaceans & Algae & Crustaceans & Crustaceans & Algae \\
\hline $\begin{array}{l}\text { Classification } \\
\text { (EU-Directive 93/67/EEC (CEC 1996) }^{\text {b }}\end{array}$ & Very toxic & Toxic & Very toxic & Very toxic & Very toxic & Very toxic \\
\hline $\begin{array}{l}\text { Classification (Sanderson et al. 2003; Blaise } \\
\text { et al. 2008) }\end{array}$ & $\begin{array}{l}\text { Extremely } \\
\text { toxic }\end{array}$ & Toxic & $\begin{array}{l}\text { Extremely } \\
\text { toxic }\end{array}$ & $\begin{array}{l}\text { Extremely } \\
\text { toxic }\end{array}$ & $\begin{array}{l}\text { Extremely } \\
\text { toxic }\end{array}$ & $\begin{array}{l}\text { Extremely } \\
\text { toxic }\end{array}$ \\
\hline
\end{tabular}

* In the brackets next to the median value, the number of data used to derive the median value is presented

Data are summarized from Supplementary Tables S3-S8 and are arranged throughout according to the decreasing sensitivity (increasing median $\mathrm{L}(\mathrm{E}) \mathrm{C} 50$ values) of test organisms to silver nanoparticles. The L(E)C50 and MIC numbers are from the following articles: Borovanský and Riley (1989), Ershov et al. (1997), McCloskey et al. (1996), Lin et al. (1996), Zhao et al. (1998), Mobley et al. (1999), Mastin and Rodgers (2000), Grass and Rensing (2001), Franklin et al. (2002), Graff et al. (2003), Harmon et al. (2003), Teitzel and Parsek (2003), Yilmaz (2003), De Boeck et al. (2004), Hsieh et al. (2004), Jonker et al. (2004), de Oliveira-Filho et al. (2004), Shakibaie and Harati (2004), Apte et al. (2005), Cho et al. (2005), Heijerick et al. (2005), Lee et al. (2005), Chen et al. (2006), Hiriart-Baer et al. (2006), Jeng and Swanson (2006), Kungolos et al. (2006), Madoni and Romeo (2006), Panáček et al. (2006), Dechsakulthorn et al. (2007), Franklin et al. (2007), Gallego et al. (2007), Zhang et al. (2007), Calafato et al. (2008), Griffitt et al. (2008), Heinlaan et al. (2008), Hernández-Sierra et al. (2008), Jin et al. (2008), Karlsson et al. (2008), Kim et al. (2008), Martínez-Castanón et al. (2008), Mortimer et al. (2008), Navarro et al. (2008), Padmavathy and Vijayaraghavan (2008), Ruparelia et al. (2008), Zhu et al. (2008), Aruoja et al. (2009), Chae et al. (2009), Foldbjerg et al. (2009), Jain et al. (2009), Kasemets et al. (2009), Kim et al. 2009a, b, Kvitek et al. (2009), Lewis and Keller (2009), Lin et al. (2009), Liu et al. (2009), Ma et al. (2009), Oliva et al. (2009), Park and Heo (2009), Pavlica et al. (2009), Sovova et al. (2009), Teodorovic et al. (2009), Wang et al. (2009), Zhu et al. (2009), Ahamed et al. (2010), Baker et al. (2010), Blinova et al. (2010), Chen et al. (2010), Contreras et al. (2010), Ebrahimpour et al. (2010), Kennedy et al. (2010), Kim et al. (2010), Laban et al. (2010), Liu et al. (2010), Meyer et al. (2010), Miao et al. (2010), Mortimer et al. (2010), Nowrouzi et al. (2010), Panjehpour et al. (2010), Song et al. (2010), Suresh et al. (2010), Wang and Guan (2010), Wong et al. (2010), Alsop and Wood (2011), Bao et al. (2011), Dua et al. (2011), Emami-Karvani and Chehrazi (2011), Foldbjerg et al. (2011), He et al. (2011), Kim et al. (2011), Kurvet et al. (2011), Lipovsky et al. (2011), Ma et al. (2011), Majzlik et al. (2011), McLaughlin and Bonzongo (2011), Mortimer et al. (2011), Murphy et al. (2011), Naddafi et al. (2011), Niazi et al. (2011), Poynton et al. (2011), Xie et al. (2011), Xiong et al. (2011), Yu et al. (2011), Zhao et al. (2011), Albers et al. (2012), Ansari et al. (2012), Binaeian et al. (2012), Blinova et al. (2012), Brandt et al. (2012), Böhmert et al. (2012), Cao et al. (2012), EllegaardJensen et al. (2012), Govindasamy and Rahuman (2012), Greulich et al. (2012), Haase et al. (2012), Harrington et al. (2012), Hassan et al. (2012), He et al. (2012), Hoheisel et al. (2012), Jo et al. (2012), Kashiwada et al. (2012), Kennedy et al. (2012), Kim et al. (2012), Kwok et al. (2012), Li et al. (2012a, b) Lim et al. (2012), Little et al. (2012), Manusadžianas et al. (2012), Monteiro et al. (2012), Oukarroum et al. (2012), Patra et al. (2012), Perreault et al. (2012), Piret et al. 2012a, b, Poynton et al. (2012), Rallo et al. (2012), Seiffert et al. (2012), Shaw et al. (2012), Shi et al. (2012), Unger and Lück (2012), Vargas-Reus et al. (2012), Wang et al. (2012a,b), Wu et al. (2012), Yang et al. (2012), Zhang et al. (2012a, b), Zhao et al. (2012), Zhao and Wang (2012), Debabrata and Giasuddin (2013), Juganson et al. (2013), Kasemets et al. (2013), Wu and Zhou (2013)

${ }^{a} V$. fischeri data were retrieved separately from other bacteria, because $V$. fischeri (also an ISO (2010) test organism) was considered as nontarget aquatic species

${ }^{b}$ Classification of NPs and their soluble salts to hazard categories adheres to EU-Directive 93/67/EEC (CEC 1996) and is based on the lowest median L(E)C50 value of the three key environmental organisms: algae, crustaceans and fish. $<1 \mathrm{mg} / \mathrm{L}=$ very toxic to aquatic organisms; $1-10 \mathrm{mg} / \mathrm{L}=$ toxic to aquatic organisms; $10-100 \mathrm{mg} / \mathrm{L}=$ harmful to aquatic organisms; $>100 \mathrm{mg} / \mathrm{L}=$ not classified

c Analogous to classification of CEC (1996) except that one category is added: $<0.1 \mathrm{mg} / \mathrm{L}=$ extremely toxic to aquatic organisms

main representative species among crustaceans was $D$. magna, among algae Pseudokirchneriella subcapitata, among nematodes Caenorhabditis elegans, among bacteria
Escherichia coli and among yeasts Saccharomyces cerevisiae. In all other groups, the dominant organism/cell type varied depending on NP type. 
Altogether 317 L(E)C50 or minimal inhibitory concentrations (MIC) values for studied NPs were retrieved. Most of the data on crustaceans, algae and fish were obtained using standardized test methods. However, the protocols of bacterial, yeast, nematode and mammalian cell assays varied considerably. Most of the retrieved data represented $\mathrm{EC} / \mathrm{LC}_{50}$ values except for bacteria where MIC values were collected as more relevant for indicating the antimicrobial properties of NPs.

Analysis of retrieved toxicity data set

Figure 6 depicts the median L(E)C50 or MIC values and the respective variation scale for the selected NPs and the respective soluble metal salts toward different groups of organisms/cells. Table 1 provides numerical median $\mathrm{L}(\mathrm{E}) \mathrm{C} 50$ values and the number of individual values used to derive the median value. The individual $\mathrm{L}(\mathrm{E}) \mathrm{C} 50$ values are shown in Supplementary Tables S3-S8.

Classification of NPs and soluble metal salts to different hazard categories was performed according to EUDirective 93/67/EEC. This classification scheme is based on the lowest median $\mathrm{L}(\mathrm{E}) \mathrm{C} 50$ value of the three key environmental organisms: algae, crustaceans and fish (CEC 1996). The lowest median $\mathrm{L}(\mathrm{E}) \mathrm{C} 50$ value $<1 \mathrm{mg} / \mathrm{L}$ classifies chemical as very toxic to aquatic organisms; $1-10 \mathrm{mg} / \mathrm{L}=$ toxic to aquatic organisms; $10-100 \mathrm{mg} /$ $\mathrm{L}=$ harmful to aquatic organisms; $>100 \mathrm{mg} / \mathrm{L}=$ not classified (CEC 1996). An additional category "extremely toxic' applied by Sanderson et al. (2003) and Blaise et al. (2008) was also employed in the current review. Note that according to EU-Directive 93/67/EEC, the lowest EC50 value obtained either in tests with crustaceans, algae or fish will determine the final hazard class of the chemical compound (Table 1).

Ag NPs exhibited the highest toxicity to the crustaceans with median $\mathrm{L}(\mathrm{E}) \mathrm{C} 50$ value of $0.01 \mathrm{mg} / \mathrm{L}$, that is, according to the most sensitive organism of the test battery crustaceans-algae-fish, Ag NPs should be classified as 'very toxic' to aquatic organisms (CEC 1996). The toxicity of $\mathrm{Ag} \mathrm{NPs}$ to algae was slightly lower (median $\mathrm{L}(\mathrm{E}) \mathrm{C} 50=0.36 \mathrm{mg} / \mathrm{L}$ ), followed by fish, nematodes, bacteria, yeast, various mammalian cells, Vibrio fischeri and protozoa (Fig. 6a; Table 1). Thus, Ag NPs that are mostly used in antimicrobials and in algaecides (Nowack et al. 2011) were the most toxic toward non-target aqueous organisms - the crustaceans that are crucial components of the aquatic food web. Toxicity data of Ag NPs on bacteria, aquatic organisms and eukaryotic cells in vitro was also recently summarized by Chernousova and Epple (2013). Similarly to our findings (Table 1), these authors showed that the MIC values of Ag NPs to bacteria were in the range of $0.1-20 \mathrm{mg} / \mathrm{L}$ and to eukaryotic cells in vitro in the range of $10-100 \mathrm{mg} / \mathrm{L}$.

It is noteworthy that the sensitivity pattern of different organisms to studied metal-containing NPs largely followed the pattern of their sensitivity to the respective metal ions. For instance, similarly to the tendency noted with $\mathrm{Ag}$ NPs, crustaceans, algae and fish proved the most sensitive organisms also to Ag ions (Fig. 6b; Table 1). As a rule, the difference between the L(E)C50 values of Ag NPs and Ag ions was 10-15 times (Fig. 7a), with the exception of nematode C. elegans for which the toxicity of Ag NPs and $\mathrm{Ag}$ ions, was nearly the same. However, most of the toxicity data on Ag NPs to C. elegans originate from the study of Yang et al. (2012), who utilized a set of toxic Ag NPs that were prepared in-house. Thus, it is difficult to conclude whether increased toxicity of Ag NPs compared to Ag ions was determined by the specific properties of Ag NPs prepared by Yang et al. (2012) or whether Ag NPs in general have more prominent particle-specific effects in C. elegans.

Similarly to Ag NPs, also CuO NPs were the most toxic to crustaceans and algae, but at a slightly higher level: median $\mathrm{L}(\mathrm{E}) \mathrm{C} 50$ values were around $2-3 \mathrm{mg} \mathrm{CuO} / \mathrm{L}$
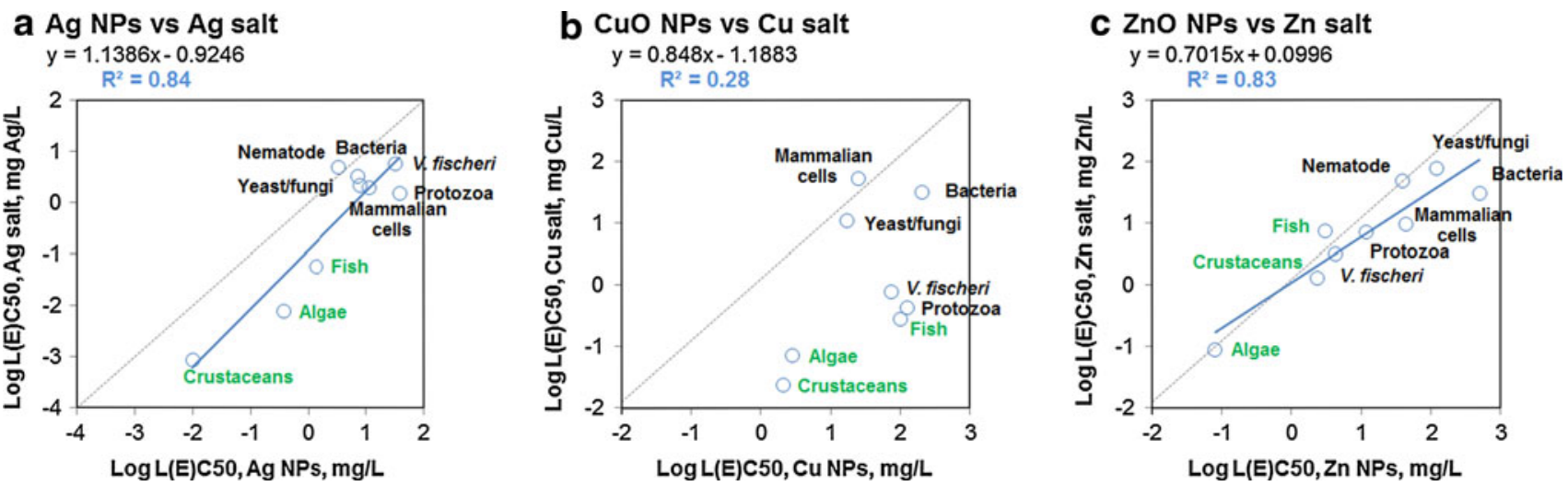

Fig. 7 Plots of the median $\mathrm{L}(\mathrm{E}) \mathrm{C} 50$ values of $\mathrm{Ag}, \mathrm{CuO}$ and $\mathrm{ZnO}$ NPs versus the median $\mathrm{L}(\mathrm{E}) \mathrm{C} 50$ values of the respective soluble metal salts to different organism groups. Data are plotted from Table 1 
(Fig. 6c; Table 1). Thus, according to the most sensitive organism of the test battery crustaceans-algae-fish, $\mathrm{CuO}$ NPs should be classified as 'toxic' to aquatic organisms (CEC 1996). As a rule, in all other ecotoxicological organisms, $\mathrm{CuO}$ NPs exerted toxicity at relatively high nominal concentrations $(\mathrm{L}(\mathrm{E}) \mathrm{C} 50>100 \mathrm{mg} / \mathrm{L})$. As $\mathrm{CuO}$ NPs are also used as antibacterials (Fig. 2c), it is interesting to note that bacteria proved not sensitive toward $\mathrm{CuO}$ NPs (MIC > $250 \mathrm{mg} / \mathrm{L}$ ). On one hand, the insensitivity of bacteria toward $\mathrm{CuO}$ NPs may be explained by the differences in the test media and toxicity endpoints used. Indeed, in the toxicity assays with crustaceans and algae a mineral medium with low potential for complexing of $\mathrm{Cu}$ ions was utilized, whereas the bacterial inhibition assays (for MIC calculation) were mostly performed in organic media with high potential for complexing of $\mathrm{Cu}$ ions. On the other hand, the bacterial MIC values were very similar to EC50 values collected for bioluminescent aquatic bacterium $V$. fischeri where the assay was performed in $2 \%$ $\mathrm{NaCl}$ (ISO 2010). Thus, apparently CuO NPs are indeed substantially more toxic to crustaceans and algae than to bacteria, and their use as antimicrobials should be perhaps re-considered due to the ecotoxicological concerns during the 'life cycle' of CuO NP-containing products.

$\mathrm{Cu}$ ions were more toxic than $\mathrm{CuO}$ NPs to all organisms except for yeast and mammalian cells in vitro (Figs. 6d, 7b). This is an important finding showing that in mammalian cells in vitro, $\mathrm{CuO}$ NPs may have an additional particle-specific intrinsic toxicity that is hard to predict using non-mammalian cell models. One may hypothesize that the particles are endocytosed (a Trojan horse model) and when already inside the cell their solubilization cannot be controlled by the mechanisms used to regulate the concentration of $\mathrm{Cu}$ ions in the cell. On the other hand, the toxicity assays with mammalian cells in vitro use serum that may disperse and coat NPs (Zook et al. 2012) increasing their bioavailability to the cells. For yeast $S$. cerevisiae, it was shown that while the toxicity tests were done in protein-rich medium, $\mathrm{CuO}$ NPs enhanced the $\mathrm{Cu}$ ion-associated stress assumingly due to the stronger sorption of protein-coated NPs onto the cell surface that was suggested to facilitate the dissolution of $\mathrm{CuO}$ in the close vicinity of the yeast cell wall. Interestingly, this effect was prominent in complex organic medium, but not in distilled water (Kasemets et al. 2013).

As in case of $\mathrm{Ag}$ and $\mathrm{CuO}$ NPs, the toxicity of $\mathrm{ZnO}$ NPs to algae (median $\mathrm{L}(\mathrm{E}) \mathrm{C} 50=0.08 \mathrm{mg} / \mathrm{L}$ ) crustaceans $(\mathrm{L}(\mathrm{E}) \mathrm{C} 50=2.3 \mathrm{mg} / \mathrm{L})$ and fish (median $\mathrm{L}(\mathrm{E}) \mathrm{C} 50=$ $3.0 \mathrm{mg} / \mathrm{L}$ ) was remarkably higher than to bacteria (MIC $622 \mathrm{mg} / \mathrm{L}$ ). Thus, according to the most sensitive organism of the test battery crustaceans-algae-fish, ZnO NPs should be classified as 'very toxic' to aquatic organisms (CEC 1996).

The toxicity of $\mathrm{ZnO}$ NPs and $\mathrm{Zn}$ ions to different organisms was stunningly similar (Figs. 6e-f, 7c; Table 1), indicating that the toxicity of ZnO NPs is largely caused by dissolved $\mathrm{Zn}$. To further illustrate the role of dissolution in the toxicity of studied NPs, the toxicity of NPs to various organisms was plotted against the toxicity of the respective metal ions. As shown in Fig. 7, the $\mathrm{L}(\mathrm{E}) \mathrm{C} 50$ values of $\mathrm{Ag}$ and $\mathrm{ZnO}$ NPs correlated well with the respective values of the soluble salts $\left(R^{2}=0.84\right.$ and 0.85 , respectively). However, the plot of the $\mathrm{L}(\mathrm{E}) \mathrm{C} 50$ values of $\mathrm{CuO}$ NPs and $\mathrm{Cu}$ ions formed two clusters, distinguishing mammalian cells, yeast and bacterial cells from all other organisms. As discussed above, this was most probably caused by the test
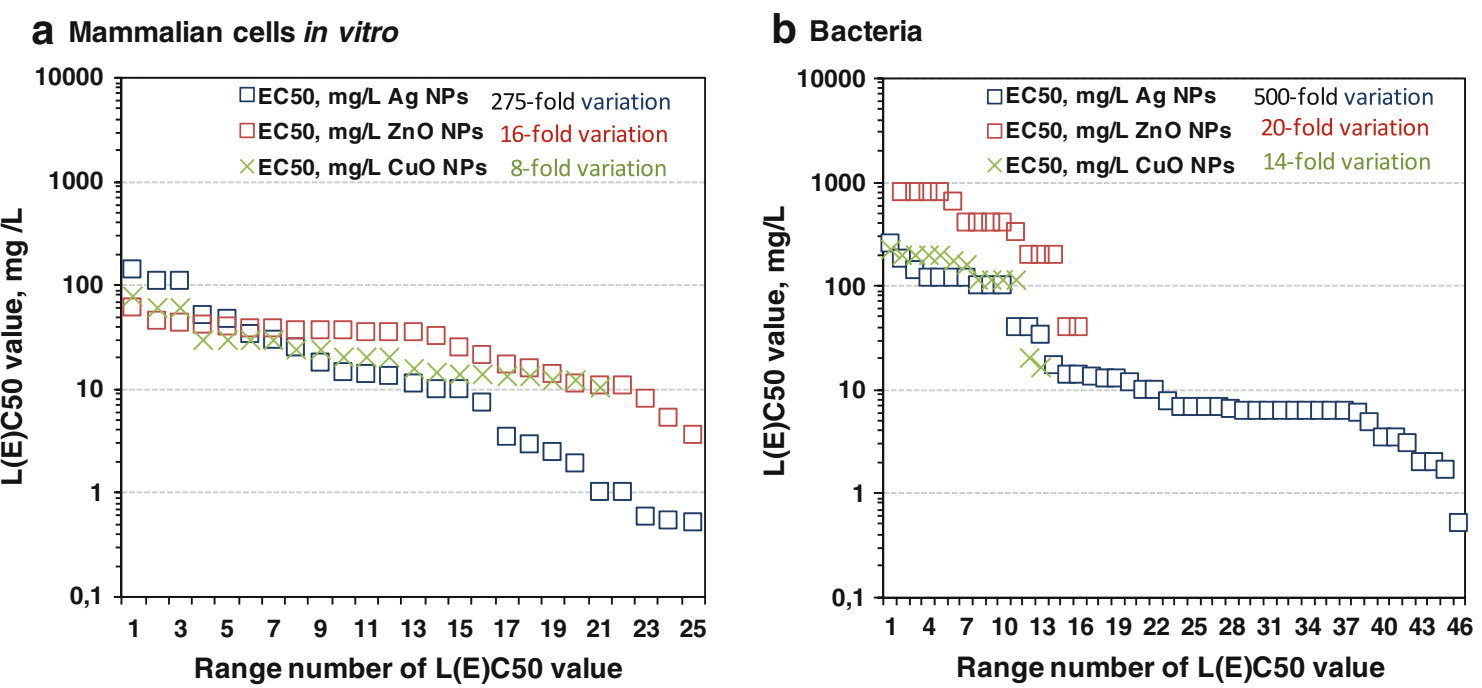

Fig. 8 Variation in individual L(E)C50 or MIC values used to derive the median L(E)C50 or MIC value for mammalian cells in vitro (a) and bacteria (b) 
environment rich in organic compounds, where organic matter enhanced dispersion of $\mathrm{CuO}$ NPs and increased their bioavailability to the cells.

\section{Variability of the retrieved toxicity data}

Finally, we analyzed the obtained toxicity data with respect to the size and coating of NPs. As most of the literature data were available for bacterial cells (74 MIC values were retrieved, Fig. 6) and mammalian cells in vitro (71 EC50 values were retrieved, Fig. 6), the comparative analysis of particle size, coating and toxicity to these two cell types was performed. In addition, the toxicity mechanisms of NPs to these cell types are supposedly different, because mammalian cells internalize NPs and bacteria are more 'resistant' to the intracellularization of NPs, although some researchers have reported the penetration of NPs also into bacterial cells (Morones et al. 2005; McQuillan et al. 2012). The toxicity data of NPs to both mammalian and bacterial cells were supposed to vary because of the heterogeneity of bacterial strains and cell lines used (Table S2).

Surprisingly, we observed that the toxicity data of $\mathrm{CuO}$ and $\mathrm{ZnO}$ NPs to both groups, mammalian and bacterial cells, varied in quite narrow range: 16 -fold and 20 -fold for $\mathrm{ZnO}$ NPs and 8-fold and 14-fold for CuO NPs, respectively (Fig. 8).

Table 2 Characterization of sizes of NPs of $\mathrm{Ag}, \mathrm{CuO}$ and $\mathrm{ZnO}$ used to derive the median MIC values in bacterial studies or $\mathrm{L}(\mathrm{E}) \mathrm{C} 50$ values in mammalian cell in vitro studies

\begin{tabular}{|c|c|c|c|c|c|c|}
\hline & \multicolumn{3}{|c|}{ Mammalian cells in vitro } & \multicolumn{3}{|c|}{ Bacteria } \\
\hline & $\mathrm{Ag}$ & $\mathrm{CuO}$ & $\mathrm{ZnO}$ & $\mathrm{Ag}$ & $\mathrm{CuO}$ & $\mathrm{ZnO}$ \\
\hline $\mathrm{Nr}$ of data & 28 & 22 & 25 & 46 & 13 & 15 \\
\hline Maximum size, $\mathrm{nm}$ & 69 & 55 & 1000 & 89 & 30 & 125 \\
\hline Median size, nm & 20 & 50 & 55 & 20 & 9.2 & 20 \\
\hline Minimum size, nm & 5 & 12 & 20 & 3.3 & 6 & 3 \\
\hline Average size, $\mathrm{nm}$ & 29.3 & 44 & 145.2 & 20 & 15.4 & 31.7 \\
\hline
\end{tabular}

In contrast, the toxicity values of Ag NPs varied greatly: 275 -fold for mammalian cells in vitro and 500-fold for bacteria. Assumingly, the differential toxicity of nanosilver was due to different coatings that were often applied on the surface of Ag nanoparticles to stabilize them. Indeed, all used $\mathrm{ZnO}$ and $\mathrm{CuO}$ NPs were uncoated (Tables S5 and S7) but $60 \%$ of Ag NPs used in studies with bacterial cells and $89 \%$ of Ag NPs used in studies with mammalian cells were coated (Table S3). In case of mammalian cells, $55 \%$ of studied Ag NPs had PVP coating, $24 \%$ had peptide coating, and $11 \%$ was uncoated. In case of bacterial cells PVP, mono- and disaccharides and biogenic coatings were reported. Interestingly, the uncoated Ag NPs were remarkably less inhibitory to bacteria than coated NPs. Specifically, to various bacterial strains 14 least inhibitory Ag NPs (MIC values $>17 \mathrm{mg} / \mathrm{L}$ ) were all uncoated. Within $32 \mathrm{Ag}$ NPs that were inhibitory to bacteria at lower than $14 \mathrm{mg} / \mathrm{L}$ concentrations 28 were coated and only 4 uncoated, whereas the type of the coating seemed to play no role (Table S3). In case of mammalian cells in vitro we did not observe analogous effect of coating (Table S3).

Finally, we analyzed the obtained toxicity data with respect to the size of NPs. Information on size of NPs for which mammalian cell and bacterial toxicity data (Tables S3, S5 and S7) were collected is shown in Table 2. The median sizes of $\mathrm{Ag}, \mathrm{CuO}$ and $\mathrm{ZnO}$ were 20,50 and $55 \mathrm{~nm}$, respectively, for mammalian cells in vitro and 20, 9.2 and $20 \mathrm{~nm}$, respectively, for bacterial cells.

Example on correlation between toxicity of Ag NPs to mammalian cells in vitro and the NPs primary size is given in Fig. 9a. To avoid the interference of coating in Ag NPs' toxicity, only PVP-coated NPs were used. When all the retrieved $\mathrm{L}(\mathrm{E}) \mathrm{C} 50$ values of PVP-coated Ag NPs to mammalian cells were plotted against the primary size on these NPs, no correlation was observed $\left(R^{2}=0.1\right)$ (Fig. 9a). At the same time, higher correlation $\left(R^{2}=0.4\right)$ was observed when the toxicity data from one single article was used (Liu et al. 2010). Finally, when the toxicity data

\section{a all PVP-coated Ag NPs}

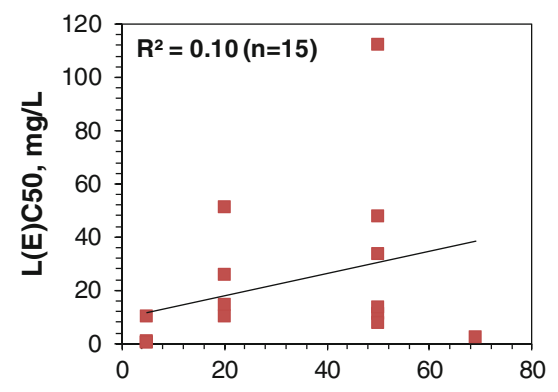

Primary size of nanoparticles, $\mathrm{nm}$

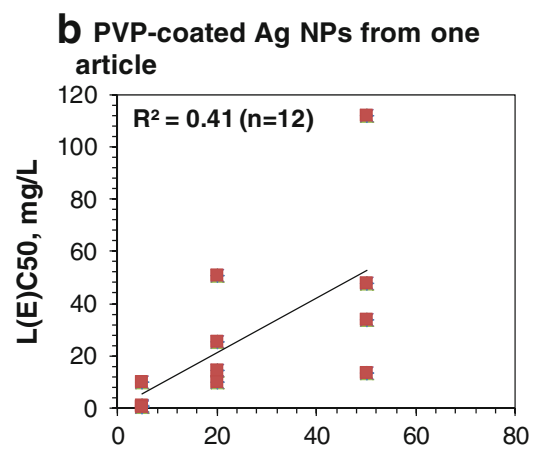

Primary size of nanoparticles, $\mathrm{nm}$

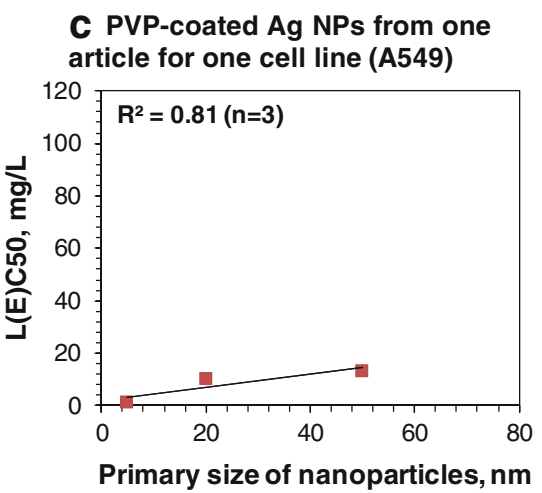

Fig. 9 L(E)C50 values of PVP-coated Ag NPs to mammalian cells versus size of nanoparticles. a All collected data were used; $\mathbf{b}$ data from one article (Liu et al. 2010) were used; $\mathbf{c}$ data from one article for one cell type were used (Liu et al. 2010) 
for one cell line from one article was used, clear correlation was observed between the size and the toxicity of NPs $\left(R^{2}=0.81\right.$, Fig. 9c). Similar observations were done for other articles that presented the toxic effects of a library of differently sized well-characterized NPs for various organism groups (Martínez-Castanón et al. 2008; Hoheisel et al. 2012; Wang et al. 2012a). These findings show clearly that the interlaboratory variations in preparation of NP suspensions and toxicity testing conditions make it difficult to draw general conclusions regarding the toxicity of NPs. At a single laboratory level, this problem may be resolved by using wellcharacterized monodisperse libraries of NPs. At the level of the whole nanotoxicology community, it is very important to proceed with the implementation of the general guidelines for nanotoxicology research to end up with the parameters that should be addressed in every nanotoxicological work, for example sufficient characterization of NPs and utilization of technically suitable toxicity tests and reference materials (Nature Nanotech Editorial 2012).

\section{Conclusions}

Our analysis of the literature data showed that:

1. The most toxic out of the three studied NPs was nanosilver. The L(E)C50 values of Ag NPs for the studied organisms/cells spanned nearly 4 orders of magnitude, from $0.01 \mathrm{mg} / \mathrm{L}$ for crustaceans to $38 \mathrm{mg} /$ $\mathrm{L}$ for protozoa. For most of the species studied, the $\mathrm{L}(\mathrm{E}) \mathrm{C} 50$ values were below $10 \mathrm{mg} / \mathrm{L}$, showing the hazardous properties of nanosilver compounds.

2. The $\mathrm{L}(\mathrm{E}) \mathrm{C}_{50}$ values of $\mathrm{CuO}$ NPs ranged from 2 to $3 \mathrm{mg} / \mathrm{L}$ for crustaceans and algae, to $>100 \mathrm{mg} / \mathrm{L}$ for protozoa and bacteria, and were in the range of $10-100 \mathrm{mg} / \mathrm{L}$ for most of the organisms studied.

3. $\mathrm{ZnO}$ NPs were the most toxic to algae $(<0.1 \mathrm{mg} / \mathrm{L})$, followed by crustaceans, fish, bacteria $V$. fischeri and protozoa. The $\mathrm{L}(\mathrm{E}) \mathrm{C} 50$ values of $\mathrm{ZnO}$ NPs were between 10 and $100 \mathrm{mg} / \mathrm{L}$ for nematodes, yeast and mammalian cells. Interestingly, $\mathrm{ZnO}$ NPs were not toxic to bacteria (median MIC $622 \mathrm{mg} / \mathrm{L}$ ).

4. The toxic effect of Ag NPs and $\mathrm{ZnO}$ NPs (but not $\mathrm{CuO}$ NPs) was seemingly explained by solubilized ions. The intraspecies differences in toxicity seem to be at least partially explained by the composition of the test medium that affects the solubilization of metalcontaining NPs and speciation of released metal ions.

5. Although bacterial cells are one of the target groups for all the studied nanoparticles, bacteria were among the least sensitive organisms. Instead, all the studied nanoparticles were remarkably more toxic to crustaceans, algae and fish.
6. Notably, one group of aquatic organisms most affected by the studied NPs was algae. This observation is noteworthy because planktonic microalgae as primary producers are the key component of food chain in aquatic ecosystems. Also, many algal species serve directly as a food source for zooplankton, which is subsequently consumed by other invertebrates or fish. Changes in the structure and productivity of the algal community may induce direct structural changes in the rest of the ecosystem and/or indirectly affect the ecosystem by affecting water quality (Nyholm and Petersen 1997).

\section{Outlook}

Crustaceans, algae and fish-the aquatic test organisms proposed for the classification and labeling of chemicals by EU REACH regulation-proved the most sensitive groups of organisms with respect to the toxic action of all three analyzed metal-containing NPs. Unexpectedly, the analysis of the published data on toxic effects of $\mathrm{Ag}, \mathrm{ZnO}$ and $\mathrm{CuO}$ NPs showed that these three biocidal NPs were inhibitory to bacteria at considerably higher level than to non-target environmental organisms. Our observation is coherent with the recent statement of Chernousova and Epple (2013) on nanosilver: 'After analyzing a multitude of single studies, it can be concluded that the effect of silver towards bacteria is typically overestimated, and towards (eukaryotic) cells it is typically underestimated. Therefore, the application of silver in consumer products, cosmetics, and medical products should be critically assessed.'

To address the environmental impact of biocidal nanomaterials, we would like additionally to emphasize the following aspect of the species sensitivity pattern toward nanomaterials: As the toxicity range for all the three metalcontaining NPs to non-target aquatic organisms and target organisms (bacteria, fungi, algae) warningly overlapped, the discharge or leaching of biocidal nanomaterials to surface waters may pose threat to aquatic species. This aspect of life cycle of nanomaterials could be controlled either at the level of 'safe by design' or, if applicable, by regulated discharge/disposal.

Acknowledgments This research was supported by the SF0690063s08, ETF8561, ETF9001 projects, EU 7th Framework Programme under Grant Agreements No. 263147 (NanoValid) and No. 309314 (MODERN), and EU Regional Development Foundation, Environmental Conservation and Environmental Technology R\&D Programme project TERIKVANT (3.2.0802.11-0043). Sciex-NMSch fellowship to M. Mortimer is acknowledged. Mr. Aleksandr Käkinen is acknowledged for the image in Fig. 4. 
Open Access This article is distributed under the terms of the Creative Commons Attribution License which permits any use, distribution, and reproduction in any medium, provided the original author(s) and the source are credited.

\section{References}

Ahamed M, Siddiqui MA, Akhtar MJ, Ahmad I, Pant AB, Alhadlaq HA (2010) Genotoxic potential of copper oxide nanoparticles in human lung epithelial cells. Biochem Biophys Res Commun 396(2):578-583

Albers CE, Hofstetter W, Siebenrock K, Landmann R, Klenke F (2012) Cytotoxic effects of ionic silver and silver nano-particles on osteoblasts and osteoclasts in vitro. J Bone Joint Surg $\mathrm{Br}$ 94-B((SUPP 37): 163

Alsop D, Wood CM (2011) Metal uptake and acute toxicity in zebrafish: common mechanisms across multiple metals. Aquat Toxicol 105(3-4):385-393

Ansari M, Khan H, Khan A, Sultan A, Azam A (2012) Characterization of clinical strains of MSSA, MRSA and MRSE isolated from skin and soft tissue infections and the antibacterial activity of $\mathrm{ZnO}$ nanoparticles. World J Microb Biot 28(4):1605-1613

Apte SC, Batley GE, Bowles KC, Brown PL, Creighton NM, Hales LT, Hyne RV, Julli M, Markich SJ, Pablo F, Rogers NJ, Stauber JL, Wilde K (2005) A comparison of copper speciation measurements with the toxic responses of three sensitive freshwater organisms. Environ Chem 2(4):320-330

Aruoja V, Dubourguier HC, Kasemets K, Kahru A (2009) Toxicity of nanoparticles of $\mathrm{CuO}, \mathrm{ZnO}$ and $\mathrm{TiO}_{2}$ to microalgae Pseudokirchneriella subcapitata. Sci Total Environ 407(4):1461-1468

Baker J, Sitthisak S, Sengupta M, Johnson M, Jayaswal RK, Morrissey JA (2010) Copper stress induces a global stress response in Staphylococcus aureus and represses sae and agr expression and biofilm formation. Appl Environ Microb 76(1):150-160

Bandyopadhyay S, Peralta-Videa JR, Hernandez-Viezcas JA, Montes MO, Keller AA, Gardea-Torresdey JL (2012) Microscopic and spectroscopic methods applied to the measurements of nanoparticles in the environment. Appl Spectrosc Rev 47(3):180-206

Bao VW, Leung KM, Qiu JW, Lam MH (2011) Acute toxicities of five commonly used antifouling booster biocides to selected subtropical and cosmopolitan marine species. Mar Pollut Bull 62(5):1147-1151

Bayat N, Rajapakse K, Marinsek-Logar R, Drobne D, Cristobal S (2013) The effects of engineered nanoparticles on the cellular structure and growth of Saccharomyces cerevisiae. Nanotoxicology. doi:10.3109/17435390.2013.788748

Binaeian E, Rashidi AM, Attar H (2012) Toxicity study of two different synthesized silver nanoparticles on bacteria Vibrio fischeri. WASET 67:1219-1225

Blaise C, Gagné F, Férard JF, Eullaffroy P (2008) Ecotoxicity of selected nano-materials to aquatic organisms. Environ Toxicol 23(5):591-598

Blinova I, Ivask A, Heinlaan M, Mortimer M, Kahru A (2010) Ecotoxicity of nanoparticles of $\mathrm{CuO}$ and $\mathrm{ZnO}$ in natural water. Environ Pollut 158(1):41-47

Blinova I, Niskanen J, Kajankari P, Kanarbik L, Käkinen A, Tenhu H, Penttinen OP, Kahru A (2012) Toxicity of two types of silver nanoparticles to aquatic crustaceans Daphnia magna and Thamnocephalus platyurus. Environ Sci Pollut Res Int. doi:10.1007/ s11356-012-1290-5
Böhmert L, Niemann B, Thünemann AF, Lampen A (2012) Cytotoxicity of peptide-coated silver nanoparticles on the human intestinal cell line Caco-2. Arch Toxicol 86(7):1107-1115

Bondarenko O, Ivask A, Käkinen A, Kahru A (2012) Sub-toxic effects of $\mathrm{CuO}$ nanoparticles on bacteria: kinetics, role of $\mathrm{Cu}$ ions and possible mechanisms of action. Environ Pollut 169:81-89

Borkow G, Gabbay J (2004) Putting copper into action: copperimpregnated products with potent biocidal activities. FASEB J 18(14):1728-1730

Borkow G, Zatcoff RC, Gabbay J (2009) Reducing the risk of skin pathologies in diabetics by using copper impregnated socks. Med Hypotheses 73(6):883-886

Borkow G, Gabbay J, Dardik R, Eidelman AI, Lavie Y, Grunfeld Y, Ikher S, Huszar M, Zatcoff RC, Marikovsky M (2010a) Molecular mechanisms of enhanced wound healing by copper oxide-impregnated dressings. Wound Repair Regen 18(2):266275

Borkow G, Zhou SS, Page T, Gabbay J (2010b) A novel antiinfluenza copper oxide containing respiratory face mask. PLoS ONE 5(6):e11295

Borovanský J, Riley PA (1989) Cytotoxicity of zinc in vitro. Chem Biol Interact 69(2-3):279-291

Brandt O, Mildner M, Egger AE, Groessl M, Rix U, Posch M, Keppler BK, Strupp C, Mueller B, Stingl G (2012) Nanoscalic silver possesses broad-spectrum antimicrobial activities and exhibits fewer toxicological side effects than silver sulfadiazine. Nanomedicine 8(4):478-488

Bystrzejewska-Piotrowska G, Golimowski J, Urban PL (2009) Nanoparticles: their potential toxicity, waste and environmental management. Waste Manag 29(9):2587-2595

Calafato S, Swain S, Hughes S, Kille P, Stürzenbaum SR (2008) Knock down of Caenorhabditis elegans cutc-1 exacerbates the sensitivity toward high levels of copper. Toxicol Sci 106(2):384-391

Cao B, Zheng Y, Xi T, Zhang C, Song W, Burugapalli K, Yang H, Ma Y (2012) Concentration-dependent cytotoxicity of copper ions on mouse fibroblasts in vitro: effects of copper ion release from TCu380A vs TCu220C intra-uterine devices. Biomed Microdevices 14(4):709-720

Carnes LC, Klabunde KJ (2003) The catalytic methanol synthesis over nanoparticle metal oxide catalysts. J Mol Catal A Chem 194(1-2):227-236

Casals E, Gonzalez E, Puntes VF (2012) Reactivity of inorganic nanoparticles in biological environments: insights into nanotoxicity mechanisms. J Phys D Appl Phys 45(44):443001

CEC (1996) CEC (Commission of the European Communities) technical guidance document in support of commission directive 93/67/EEC on risk assessment for new notified substances. Part II, Environmental Risk Assessment. Office for official publications of the European Communities, Luxembourg

Cerkez I, Kocer HB, Worley SD, Broughton RM, Huang TS (2012) Multifunctional cotton fabric: antimicrobial and durable press. J Appl Polym Sc 124(5):4230-4238

Chae YJ, Pham CH, Lee J, Bae E, Yi J, Gu MB (2009) Evaluation of the toxic impact of silver nanoparticles on Japanese medaka (Oryzias latipes). Aquat Toxicol 94(4):320-327

Chen X, Shi J, Chen Y, Xu X, Xu S, Wang Y (2006) Tolerance and biosorption of copper and zinc by Pseudomonas putida $\mathrm{CZ1}$ isolated from metal-polluted soil. Can J Microbiol 52(4):308-316

Chen QL, Luo Z, Liu X, Song YF, Liu CX, Zheng JL, Zhao YH (2010) Effects of waterborne chronic copper exposure on hepatic lipid metabolism and metal-element composition in Synechogobius hasta. Arch Environ Contam Toxicol 73:1286-1291 
Chernousova S, Epple M (2013) Silver as antibacterial agent: ion, nanoparticle, metal. Angew Chem. doi:10.1002/anie.201205923

Cho K-H, Park J-E, Osaka T, Park S-G (2005) The study of antimicrobial activity and preservative effects of nanosilver ingredient. Electrochim Acta 51(5):956-960

Contreras RG, Sakagami H, Nakajima H, Shimada J (2010) Type of cell death induced by various metal cations in cultured human gingival fibroblasts. In Vivo 24(4):513-517

Crane M, Handy RD, Garrod J, Owen R (2008) Ecotoxicity test methods and environmental hazard assessment for engineered nanoparticles. Ecotoxicology 17(5):421-437

Dastjerdi R, Montazer M (2010) A review on the application of inorganic nano-structured materials in the modification of textiles: focus on anti-microbial properties. Colloid Surf B 79(1):5-18

De Boeck G, Meeus W, De Coen W, Blust R (2004) Tissue-specific $\mathrm{Cu}$ bioaccumulation patterns and differences in sensitivity to waterborne $\mathrm{Cu}$ in three freshwater fish: rainbow trout $(\mathrm{On}$ corhynchus mykiss), common carp (Cyprinus carpio), and gibel carp (Carassius auratus gibelio). Aquat Toxicol 70(3):179-188

de Oliveira-Filho EC, Lopes RM, Paumgartten FJ (2004) Comparative study on the susceptibility of freshwater species to copperbased pesticides. Chemosphere 56(4):369-374

Debabrata D, Giasuddin A (2013) Cellular responses of Saccharomyces cerevisiae to silver nanoparticles. Res J Biotech 8(1):11

Dechsakulthorn F, Hayes A, Bakand S, Joeng L, Winder C (2007) In vitro cytotoxicity assessment of selected nanoparticles using human skin fibroblasts. AATEX 14(Special Issue):397-400

Dimkpa CO, Calder A, Britt DW, McLean JE, Anderson AJ (2011) Responses of a soil bacterium, Pseudomonas chlororaphis O6 to commercial metal oxide nanoparticles compared with responses to metal ions. Environ Pollut 159(7):1749-1756

Dua P, Chaudhari KN, Lee CH, Chaudhari NK, Hong SW, Yu JS, Kim S, Lee D (2011) Evaluation of toxicity and gene expression changes triggered by oxide nanoparticles. Bull Korean Chem Soc 2(6):2051

Ebrahimnia-Bajestan E, Niazmand H, Duangthongsuk W, Wongwises $S$ (2011) Numerical investigation of effective parameters in convective heat transfer of nanofluids flowing under a laminar flow regime. Int J Heat Mass Transf 54(19-20):4376-4388

Ebrahimpour M, Alipour H, Rakhshah S (2010) Influence of water hardness on acute toxicity of copper and zinc on fish. Toxicol Ind Health 26(6):361-365

EC (2008) Follow-up to the 6th Meeting of the REACH Competent Authorities for the implementation of Regulation (EC) 1907/2006; (REACH). European Commission, Brussels, Belgium. http://ec.europa.eu/environment/chemicals/reach/pdf/nanomaterials. pdf

Ellegaard-Jensen L, Jensen KA, Johansen A (2012) Nano-silver induces dose-response effects on the nematode Caenorhabditis elegans. Ecotoxicol Environ Saf 80:216-223

Emami-Karvani Z, Chehrazi P (2011) Antibacterial activity of ZnO nanoparticle on grampositive and gram-negative bacteria. Afr $\mathrm{J}$ Microbiol Res 5(12):1368-1373

Ershov YuA, Pleteneva TV, Slonskaya TK (1997) Evaluation of biological activity of toxic agents in a unicellular model. Bull Exp Biol Med 123(5):519-524

European Commission (2007) SCENIHR (EU Scientific Committee on Emerging and Newly identified health risks). Report "Opinion on the appropriateness of the risk assessment methodology in accordance with the technical guidance documents for new and existing substances for assessing the risks of nanomaterials". http://ec.europa.eu/health/ph_risk/committees/04_scenihr/docs/ scenihr_o_004c.pdf

European Commission (2013) Communication from the Commission to the European Parliament, the Council and the European
Economic and Social Committee. Second regulatory review on nanomaterials. Brussels, 3.10.2012, COM(2012) 572 final

European Parliament and European Council (2006) Directive 2006/121/EC. Off J Eur Union 561(L396):850

European Union (2011) Commission Regulation No 286/2011 of 10 March 2011 amending, for the purposes of its adaptation to technical and scientific progress, Regulation (EC) No 1272/2008 of the European Parliament and of the Council on classification, labelling and packaging of substances and mixtures. http://eurlex.europa.eu/LexUriServ/LexUriServ.do?uri=OJ:L:2011:083:0001: 0053:en:PDF

Fabrega J, Luoma SN, Tyler CR, Galloway TS, Lead JR (2011) Silver nanoparticles: behaviour and effects in the aquatic environment. Environ Int 37(2):517-531

Foldbjerg R, Olesen P, Hougaard M, Dang DA, Hoffmann HJ, Autrup $\mathrm{H}$ (2009) PVP-coated silver nanoparticles and silver ions induce reactive oxygen species, apoptosis and necrosis in THP-1 monocytes. Toxicol Lett 190(2):156-162

Foldbjerg R, Dang DA, Autrup H (2011) Cytotoxicity and genotoxicity of silver nanoparticles in the human lung cancer cell line, A549. Arch Toxicol 85(7):743-750

Franklin NM, Stauber JL, Lim RP, Petocz P (2002) Toxicity of metal mixtures to a tropical freshwater alga (Chlorella $\mathrm{sp}$.): the effect of interactions between copper, cadmium, and zinc on metal cell binding and uptake. Environ Toxicol Chem 21(11):2412-2422

Franklin NM, Rogers NJ, Apte SC, Batley GE, Gadd GE, Casey PS (2007) Comparative toxicity of nanoparticulate $\mathrm{ZnO}$, bulk $\mathrm{ZnO}$, and $\mathrm{ZnCl}_{2}$ to a freshwater microalga (Pseudokirchneriella subcapitata): the importance of particle solubility. Environ Sci Technol 41(24):8484-8490

Gabbay J, Mishal J, Magen E, Zatcoff RC, Shemer-Avni Y, Borkow G (2006) Copper oxide impregnated textiles with potent biocidal activities. J Ind Textil 35:323-335

Gallego A, Martín-González A, Ortega R, Gutiérrez JC (2007) Flow cytometry assessment of cytotoxicity and reactive oxygen species generation by single and binary mixtures of cadmium, zinc and copper on populations of the ciliated protozoan Tetrahymena thermophila. Chemosphere 68(4):647-661

Gao J, Youn S, Hovsepyan A, Llaneza VL, Wang Y, Bitton G, Bonzongo JC (2009) Dispersion and toxicity of selected manufactured nanomaterials in natural river water samples: effects of water chemical composition. Environ Sci Technol 43(9):3322-3328

Govindasamy R, Rahuman AA (2012) Histopathological studies and oxidative stress of synthesized silver nanoparticles in Mozambique tilapia (Oreochromis mossambicus). J Environ Sci 24(6): 1091-1098

Graff L, Isnard P, Cellier P, Bastide J, Cambon JP, Narbonne JF, Budzinski H, Vasseur P (2003) Toxicity of chemicals to microalgae in river and in standard waters. Environ Toxicol Chem 22(6):1368-1379

Grass G, Rensing C (2001) Genes involved in copper homeostasis in Escherichia coli. J Bacteriol 183(6):2145-2147

Greulich C, Braun D, Peetsch A, Diendorf J, Siebers B, Epple M, Koller M (2012) The toxic effect of silver ions and silver nanoparticles towards bacteria and human cells occurs in the same concentration range. RSC Adv 2(17):6981-6987

Griffitt RJ, Luo J, Gao J, Bonzongo JC, Barber DS (2008) Effects of particle composition and species on toxicity of metallic nanomaterials in aquatic organisms. Environ Toxicol Chem 27(9):1972-1978

Guo Z, Ng HW, Yee GL, Hahn HT (2009) Differential scanning calorimetry investigation on vinyl ester resin curing process for polymer nanocomposite fabrication. J Nanosci Nanotechnol 9(5):3278-3285

Haase A, Mantion A, Graf P, Plendl J, Thuenemann AF, Meier W, Taubert A, Luch A (2012) A novel type of silver nanoparticles 
and their advantages in toxicity testing in cell culture systems. Arch Toxicol 86(7):1089-1098

Handy RD, Cornelis G, Fernandes T, Tsyusko O, Decho A, SaboAttwood T, Metcalfe C, Steevens JA, Klaine SJ, Koelmans AA, Horne N (2012) Ecotoxicity test methods for engineered nanomaterials: practical experiences and recommendations from the bench. Environ Toxicol Chem 31(1):15-31

Harmon SM, Specht WL, Chandler GT (2003) A comparison of the daphnids Ceriodaphnia dubia and Daphnia ambigua for their utilization in routine toxicity testing in the Southeastern United States. Arch Environ Contam Toxicol 45(1):79-85

Harrington JM, Boyd WA, Smith MV, Rice JR, Freedman JH, Crumbliss AL (2012) Amelioration of metal-induced toxicity in Caenorhabditis elegans: utility of chelating agents in the bioremediation of metals. Toxicol Sci 129(1):49-56

Hassan MS, Amna T, Yang OB, El-Newehy MH, Al-Deyab SS, Khil M-S (2012) Smart copper oxide nanocrystals: synthesis, characterization, electrochemical and potent antibacterial activity. Colloid Surf B 97:201-206

He L, Liu Y, Mustapha A, Lin M (2011) Antifungal activity of zinc oxide nanoparticles against Botrytis cinerea and Penicillium expansum. Microbiol Res 166(3):207-215

He D, Dorantes-Aranda JJ, Waite TD (2012) Silver nanoparticlealgae interactions: oxidative dissolution, reactive oxygen species generation and synergistic toxic effects. Environ Sci Technol 46(16):8731-8738

Heijerick DG, Bossuyt BT, De Schamphelaere KA, Indeherberg M, Mingazzini M, Janssen CR (2005) Effect of varying physicochemistry of European surface waters on the copper toxicity to the green alga Pseudokirchneriella subcapitata. Ecotoxicology 14(6):661-670

Heinlaan M, Ivask A, Blinova I, Dubourguier HC, Kahru A (2008) Toxicity of nanosized and bulk $\mathrm{ZnO}, \mathrm{CuO}$ and $\mathrm{TiO}_{2}$ to bacteria Vibrio fischeri and crustaceans Daphnia magna and Thamnocephalus platyurus. Chemosphere 71(7):1308-1316

Hernández-Sierra JF, Ruiz F, Cruz Pena DC, Martínez-Gutiérrez F, Martínez AE, Jesús Pozos Guillén A, Tapia-Pérez H, Martínez Castañón G (2008) The antimicrobial sensitivity of Streptococcus mutans to nanoparticles of silver, zinc oxide, and gold. Nanomed-Nanotechnol 4(3):237-240

Hiriart-Baer VP, Fortin C, Lee DY, Campbell PG (2006) Toxicity of silver to two freshwater algae, Chlamydomonas reinhardtii and Pseudokirchneriella subcapitata, grown under continuous culture conditions: influence of thiosulphate. Aquat Toxicol 78(2):136-148

Hoheisel SM, Diamond S, Mount D (2012) Comparison of nanosilver and ionic silver toxicity in Daphnia magna and Pimephales promelas. Environ Toxicol Chem 31(11):2557-2563

Hsieh CY, Tsai MH, Ryan DK, Pancorbo OC (2004) Toxicity of the 13 priority pollutant metals to Vibrio fisheri in the Microtox chronic toxicity test. Sci Total Environ 320(1):37-50

IPPIC (International Paint and Printing Ink Council) (2012) http:// www.ippic.org/site/assets/docs/Public\%20AFWG/IPPIC\%20\% 20Zinc $\% 20$ oxide $\% 20-\% 20$ regulatory $\% 20$ status $\% 20$-final $\%$ 20Draft\%20March\%201\%202012.pdf

ISO 21338:2010, Water quality-Kinetic determination of the inhibitory effects of 412 sediment, other solids and coloured samples on the light emission of Vibrio fischeri 413 (kinetic luminescent bacteria test)

Ivask A, Bondarenko O, Jepihhina N, Kahru A (2010) Profiling of the reactive oxygen species-related ecotoxicity of $\mathrm{CuO}, \mathrm{ZnO}, \mathrm{TiO}_{2}$, silver and fullerene nanoparticles using a set of recombinant luminescent Escherichia coli strains: differentiating the impact of particles and solubilised metals. Anal Bioanal Chem 398:701-716

Ivask A, George S, Bondarenko O, Kahru A (2012) Metal-containing nano-antimicrobials: differentiating the impact of solubilized metals and particles. In: Cioffi N, Rai M (eds) Nano-antimicrobials: Progress and Prospects. Springer, Berlin, pp 253-290

Jain J, Arora S, Rajwade JM, Omray P, Khandelwal S, Paknikar KM (2009) Silver nanoparticles in therapeutics: development of an antimicrobial gel formulation for topical use. Mol Pharm 6(5):1388-1401

Jeng HA, Swanson J (2006) Toxicity of metal oxide nanoparticles in mammalian cells. J Environ Sci Heal A 41(12):2699-2711

Jin YH, Dunlap PE, McBride SJ, Al-Refai H, Bushel PR, Freedman JH (2008) Global transcriptome and deletome profiles of yeast exposed to transition metals. PLoS Genet 4(4):e1000053

Jo HJ, Choi JW, Lee SH, Hong SW (2012) Acute toxicity of Ag and $\mathrm{CuO}$ nanoparticle suspensions against Daphnia magna: the importance of their dissolved fraction varying with preparation methods. J Hazard Mater 227-228:301-308

Jonker MJ, Piskiewicz AM, Ivorra i Castellà N, Kammenga JE (2004) Toxicity of binary mixtures of cadmium-copper and carbendazim-copper to the nematode Caenorhabditis elegans. Environ Toxicol Chem 23(6):1529-1537

Juganson K, Mortimer M, Ivask A, Kasemets K, Kahru A (2013) Extracellular conversion of silver ions into silver nanoparticles by protozoan Tetrahymena thermophila. Environ Sci Process Impacts 15(1):244-250

Kahru A, Dubourguier HC (2010) From ecotoxicology to nanoecotoxicology. Toxicology 269(2-3):105-119

Kahru A, Ivask A (2013) Mapping the dawn of nanoecotoxicological research. Acc Chem Res 46(3):823-833

Kahru A, Savolainen K (2010) Potential hazard of nanoparticles: from properties to biological and environmental effects. Toxicology 269(2-3):89-91

Kahru A, Dubourguier HC, Blinova I, Ivask A, Kasemets K (2008) Biotests and biosensors for ecotoxicology of metal oxide nanoparticles: a minireview. Sensors 8(8):5153-5170

Käkinen A, Bondarenko O, Ivask A, Kahru A (2011) The effect of composition of different ecotoxicological test media on free and bioavailable copper from $\mathrm{CuSO}_{4}$ and $\mathrm{CuO}$ nanoparticles: comparative evidence from a $\mathrm{Cu}$-selective electrode and a $\mathrm{Cu}$ biosensor. Sensors 11(11):10502-10521

Karlsson HL, Cronholm P, Gustafsson J, Möller L (2008) Copper oxide nanoparticles are highly toxic: a comparison between metal oxide nanoparticles and carbon nanotubes. Chem Res Toxicol 21(9):1726-1732

Kasemets K, Ivask A, Dubourguier HC, Kahru A (2009) Toxicity of nanoparticles of $\mathrm{ZnO}, \mathrm{CuO}$ and $\mathrm{TiO}_{2}$ to yeast Saccharomyces cerevisiae. Toxicol In Vitro 23:1116-1122

Kasemets K, Suppi S, Künnis K, Kahru A (2013) Toxicity of CuO nanoparticles to yeast Saccharomyces cerevisiae BY4741 wildtype and its nine isogenic single-gene deletion mutants. Chem Res Toxicol 26(3):356-367

Kashiwada S, Ariza ME, Kawaguchi T, Nakagame Y, Jayasinghe BS, Gärtner K, Nakamura H, Kagami Y, Sabo-Attwood T, Ferguson PL, Chandler GT (2012) Silver nanocolloids disrupt medaka embryogenesis through vital gene expressions. Environ Sci Technol 46(11):6278-6287

Kennedy AJ, Hull MS, Bednar AJ, Goss JD, Gunter JC, Bouldin JL, Vikesland PJ, Steevens JA (2010) Fractionating nanosilver: importance for determining toxicity to aquatic test organisms. Environ Sci Technol 44(24):9571-9577

Kennedy AJ, Chappell MA, Bednar AJ, Ryan AC, Laird JG, Stanley JK, Steevens JA (2012) Impact of organic carbon on the stability and toxicity of fresh and stored silver nanoparticles. Environ Sci Technol 46(19):10772-10780

Kim KJ, Sung WS, Moon SK, Choi JS, Kim JG, Lee DG (2008) Antifungal effect of silver nanoparticles on dermatophytes. J Microbiol Biotechnol 18(8):1482-1484 
Kim KJ, Sung WS, Suh BK, Moon SK, Choi JS, Kim JG, Lee DG (2009a) Antifungal activity and mode of action of silver nanoparticles on Candida albicans. Biometals 22(2):235-242

Kim S, Choi JE, Choi J, Chung KH, Park K, Yi J, Ryu DY (2009b) Oxidative stress-dependent toxicity of silver nanoparticles in human hepatoma cells. Toxicol In Vitro 23(6):1076-1084

Kim YH, Fazlollahi F, Kennedy IM, Yacobi NR, Hamm-Alvarez SF, Borok Z, Kim KJ, Crandall ED (2010) Alveolar epithelial cell injury due to zinc oxide nanoparticle exposure. Am J Respir Crit Care Med 182(11):1398-1409

Kim J, Kim S, Lee S (2011) Differentiation of the toxicities of silver nanoparticles and silver ions to the Japanese medaka (Oryzias latipes) and the cladoceran Daphnia magna. Nanotoxicology 5(2):208-214

Kim SW, Nam SH, An YJ (2012) Interaction of silver nanoparticles with biological surfaces of Caenorhabditis elegans. Ecotoxicol Environ Saf 77:64-70

Kungolos A, Samaras P, Tsiridis V, Petala M, Sakellaropoulos G (2006) Bioavailability and toxicity of heavy metals in the presence of natural organic matter. J Environ Sci Heal A 41(8):1509-1517

Kurvet I, Ivask A, Bondarenko O, Sihtmäe M, Kahru A (2011) LuxCDABE-transformed constitutively bioluminescent Escherichia coli for toxicity screening: comparison with naturally luminous Vibrio fischeri. Sensors 11(8):7865-7878

Kvitek L, Vanickova M, Panacek A, Soukupova J, Dittrich M, Valentova E, Prucek R, Bancirova M, Milde D, Zboril R (2009) Initial study on the toxicity of silver nanoparticles (NPs) against Paramecium caudatum. J Phys Chem C 113(11):4296-4300

Kwok KW, Auffan M, Badireddy AR, Nelson CM, Wiesner MR, Chilkoti A, Liu J, Marinakos SM, Hinton DE (2012) Uptake of silver nanoparticles and toxicity to early life stages of Japanese medaka (Oryzias latipes): effect of coating materials. Aquat Toxicol 120-121:59-66

Laban G, Nies LF, Turco RF, Bickham JW, Sepúlveda MS (2010) The effects of silver nanoparticles on fathead minnow (Pimephales promelas) embryos. Ecotoxicology 19(1):185-195

Lee DY, Fortin C, Campbell PG (2005) Contrasting effects of chloride on the toxicity of silver to two green algae, Pseudokirchneriella subcapitata and Chlamydomonas reinhardtii. Aquat Toxicol 75(2):127-135

Levard C, Hotze EM, Lowry GV, Brown GE Jr (2012) Environmental transformations of silver nanoparticles: impact on stability and toxicity. Environ Sci Technol 46(13):6900-6914

Lewis SS, Keller SJ (2009) Identification of copper-responsive genes in an early life stage of the fathead minnow Pimephales promelas. Ecotoxicology 18(3):281-292

Li Y, Liang J, Tao Z, Chen J (2007) CuO particles and plates: synthesis and gas-sensor application. Mater Res Bull 43:2380-2385

Li K, Chen Y, Zhang W, Pu Z, Jiang L, Chen Y (2012a) Surface interactions affect the toxicity of engineered metal oxide nanoparticles toward Paramecium. Chem Res Toxicol 25(8):1675-1681

Li J, Liu X, Zhang Y, Tian F, Zhao G, Yu O, Jiang FI, Liu Y (2012b) Toxicity of nano zinc oxide to mitochondria. Toxicol Res 1:137-144

Lian W, Liu S, Yu J, Li J, Cui M, Xu W, Huang J (2013) Electrochemical sensor using neomycin-imprinted film as recognition element based on chitosan-silver nanoparticles/graphene-multiwalled carbon nanotubes composites modified electrode. Biosens Bioelectron 15(44):70-76

Lim D, Roh JY, Eom HJ, Choi JY, Hyun J, Choi J (2012) Oxidative stress-related PMK-1 P38 MAPK activation as a mechanism for toxicity of silver nanoparticles to reproduction in the nematode Caenorhabditis elegans. Environ Toxicol Chem 31(3):585-592
Lin Y-SE, Vidic RD, Stout JE, Yu VL (1996) Individual and combined effects of copper and silver ions on inactivation of Legionella pneumophila. Water Res 30(8):1905-1913

Lin W, Xu Y, Huang C-C, Ma Y, Shannon KB, Chen D-R, Huang Y-W (2009) Toxicity of nano and micro-sized $\mathrm{ZnO}$ particles in human lung epithelial cells. J Nanopart Res 11:25-39

Lipovsky A, Nitzan Y, Gedanken A, Lubart R (2011) Antifungal activity of $\mathrm{ZnO}$ nanoparticles-the role of ROS mediated cell injury. Nanotechnology 22(10):105101

Little EE, Calfee RD, Linder G (2012) Toxicity of copper to early-life stage Kootenai River white sturgeon, Columbia River white sturgeon, and rainbow trout. Arch Environ Contam Toxicol 63(3):400-408

Liu Y, He L, Mustapha A, Li H, Hu ZQ, Lin M (2009) Antibacterial activities of zinc oxide nanoparticles against Escherichia coli O157:H7. J Appl Microbiol 107(4):1193-1201

Liu W, Wu Y, Wang C, Li HC, Wang T, Liao CY, Cui L, Zhou QF, Yan B, Jiang GB (2010) Impact of silver nanoparticles on human cells: effect of particle size. Nanotoxicology 4(3):319-330

Lux Research (2008) Nanomaterials State of the Market Q3 2008: Stealth Success, Broad Impact. Report. https://portal.luxresearchinc. com/research/document_excerpt/3735

Ma H, Bertsch PM, Glenn TC, Kabengi NJ, Williams PL (2009) Toxicity of manufactured zinc oxide nanoparticles in the nematode Caenorhabditis elegans. Environ Toxicol Chem 28(6):1324-1330

Ma H, Kabengi NJ, Bertsch PM, Unrine JM, Glenn TC, Williams PL (2011) Comparative phototoxicity of nanoparticulate and bulk $\mathrm{ZnO}$ to a free-living nematode Caenorhabditis elegans: the importance of illumination mode and primary particle size. Environ Pollut 159(6):1473-1480

Ma H, Williams PL, Diamond SA (2013) Ecotoxicity of manufactured $\mathrm{ZnO}$ nanoparticles-a review. Environ Pollut 172:76-85

Madoni P, Romeo MG (2006) Acute toxicity of heavy metals towards freshwater ciliated protists. Environ Pollut 141(1):1-7

Majzlik P, Strasky A, Adam V, Nemec M, Trnkova L, Zehnalek J, Hubalek J, Provaznik I, Kizek R (2011) Influence of zinc(II) and copper(II) ions on Streptomyces bacteria revealed by electrochemistry. Int J Electrochem Sci 6:2171-2191

Manusadžianas L, Caillet C, Fachetti L, Gylytė B, Grigutytė R, Jurkoniene S, Karitonas R, Sadauskas K, Thomas F, Vitkus R, Férard JF (2012) Toxicity of copper oxide nanoparticle suspensions to aquatic biota. Environ Toxicol Chem 31(1):108-114

Marambio-Jones C, Hoek EMV (2010) A review of the antibacterial effects of silver nanomaterials and potential implications for human health and the environment. J Nanopart Res 12:1531-1551

Martínez-Castanón G, Nino-Martínez N, Martínez-Gutierrez F, Martínez-Mendoza J, Ruiz F (2008) Synthesis and antibacterial activity of silver nanoparticles with different sizes. J Nanopart Res 10(8):1343-1348

Mastin BJ, Rodgers JH Jr (2000) Toxicity and bioavailability of copper herbicides (Clearigate, Cutrine-Plus, and copper sulfate) to freshwater animals. Arch Environ Contam Toxicol 39(4):445-451

McCloskey JT, Newman MC, Clark SB (1996) Predicting relative toxicity of metal ions using ion characteristics: microtoxs bioluminescence assay. Environ Toxicol Chem 15:1730-1737

McLaughlin J, Bonzongo JC (2011) Effects of natural water chemistry on nanosilver behavior and toxicity to Ceriodaphnia dubia and Pseudokirchneriella subcapitata. Environ Toxicol Chem 31(1):168-175

McQuillan JS, Infante GH, Stokes E, Shaw AM (2012) Silver nanoparticle enhanced silver ion stress response in Escherichia coli K12. Nanotoxicology 6:857-866 
Meyer JN, Lord CA, Yang XY, Turner EA, Badireddy AR, Marinakos SM, Chilkoti A, Wiesner MR, Auffan M (2010) Intracellular uptake and associated toxicity of silver nanoparticles in Caenorhabditis elegans. Aquat Toxicol 100(2):140-150

Miao AJ, Luo Z, Chen CS, Chin WC, Santschi PH, Quigg A (2010) Intracellular uptake: a possible mechanism for silver engineered nanoparticle toxicity to a freshwater alga Ochromonas danica. PLOS ONE 5(12):e15196

Mobley HL, Garner RM, Chippendale GR, Gilbert JV, Kane AV, Plaut AG (1999) Role of Hpn and NixA of Helicobacter pylori in susceptibility and resistance to bismuth and other metal ions. Helicobacter 4(3):162-169

Monteiro DR, Silva S, Negri M, Gorup LF, de Camargo ER, Oliveira R, Barbosa DB, Henriques M (2012) Silver nanoparticles: influence of stabilizing agent and diameter on antifungal activity against Candida albicans and Candida glabrata biofilms. Lett Appl Microbiol 54(5):383-391

Morones JR, Elechiguerra JL, Camacho A, Holt K, Kouri JB, Ramírez JT, Yacaman MJ (2005) The bactericidal effect of silver nanoparticles. Nanotechnology 16:2346-2353

Mortimer M, Kasemets K, Heinlaan M, Kurvet I, Kahru A (2008) High throughput kinetic Vibrio fischeri bioluminescence inhibition assay for study of toxic effects of nanoparticles. Toxicol In Vitro 22:1412-1417

Mortimer M, Kasemets K, Kahru A (2010) Toxicity of $\mathrm{ZnO}$ and $\mathrm{CuO}$ nanoparticles to ciliated protozoa Tetrahymena thermophila. Toxicology 269(2-3):182-189

Mortimer M, Kasemets K, Vodovnik M, Marinsek-Logar R, Kahru A (2011) Exposure to $\mathrm{CuO}$ nanoparticles changes the fatty acid composition of protozoa Tetrahymena thermophila. Environ Sci Technol 45(15):6617-6624

Murphy JT, Bruinsma JJ, Schneider DL, Collier S, Guthrie J, Chinwalla A, Robertson JD, Mardis ER, Kornfeld K (2011) Histidine protects against zinc and nickel toxicity in Caenorhabditis elegans. PLoS Genet 7(3):e1002013

Naddafi K, Zare MR, Nazmara S (2011) Investigating potential toxicity of phenanthrene adsorbed to nano-ZnO using Daphnia magna. Toxicol Environ Chem 93(4):729-737

Nair LS, Laurencin CT (2007) Silver nanoparticles: synthesis and therapeutic applications. J Biomed Nanotechnol 3:301-316

Nature Nanotech Editorial (2012) 7(9):545

Navarro E, Piccapietra F, Wagner B, Marconi F, Kaegi R, Odzak N, Sigg L, Behra R (2008) Toxicity of silver nanoparticles to Chlamydomonas reinhardtii. Environ Sci Technol 42(23):8959-8964

Nel A, Xia T, Mädler L, Li N (2006) Toxic potential of materials at the nanolevel. Science 311:622-662

Niazi JH, Sang BI, Kim YS, Gu MB (2011) Global gene response in Saccharomyces cerevisiae exposed to silver nanoparticles. Appl Biochem Biotechnol 164(8):1278-1291

Nowack B, Krug HF, Height M (2011) 120 Years of nanosilver history: implications for policy makers. Environ Sci Technol 45(4): $1177-1183$

Nowrouzi A, Meghrazi K, Golmohammadi T, Golestani A, Ahmadian S, Shafiezadeh M, Shajary Z, Khaghani S, Amiri AN (2010) Cytotoxicity of subtoxic AgNP in human hepatoma cell line (HepG2) after long-term exposure. Iran Biomed J 14(1-2):23-32

Nyholm N, Petersen HG (1997) Laboratory bioassays with microalgae. In: Wang W, Gorsuch JW, Hughes JS (eds) Plants for environmental studies. Lewis Publishers, Boca Raton Chapter 9

OECD (1992) Guidelines for the testing of chemicals. Section 2: Effects on Biotic Systems. Test No. 203: Fish, acute toxicity test. Organisation for Economic Co-operation and Development, Paris, France

OECD (2004) Guidelines for the testing of chemicals. Section 2: Effects on Biotic Systems. Test No. 202: Daphnia sp. acute immobilisation test. Organisation for Economic Co-operation and Development, Paris, France

OECD (2011) Guidelines for the testing of chemicals. Section 2: Effects on Biotic Systems. Test No. 201: Freshwater Alga and Cyanobacteria, growth inhibition test. Organisation for Economic Co-operation and Development, Paris, France

Oliva M, Garrido MC, Sales Márquez D, González de Canales ML (2009) Sublethal and lethal toxicity in juvenile Senegal sole (Solea senegalensis) exposed to copper: a preliminary toxicity range-finding test. Exp Toxicol Pathol 61(2):113-121

Oukarroum A, Bras S, Perreault F, Popovic R (2012) Inhibitory effects of silver nanoparticles in two green algae, Chlorella vulgaris and Dunaliella tertiolecta. Ecotoxicol Environ Saf 78:80-85

Padmavathy N, Vijayaraghavan R (2008) Enhanced bioactivity of $\mathrm{ZnO}$ nanoparticles-an antimicrobial study. Sci Technol Adv Mater 9(3):035004

Panáček A, Kvítek L, Prucek R, Kolár M, Večeřová R, Pizúrová N, Sharma VK, Nevěčná T, Zbořil R (2006) Silver colloid nanoparticles: synthesis, characterization, and their antibacterial activity. J Phys Chem B 110(33):16248-16253

Panjehpour M, Taher MA, Bayesteh M (2010) The growth inhibitory effects of cadmium and copper on the MDA-MB468 human breast cancer cells. J Res Med Sci 15(5):279-286

Park K, Heo GJ (2009) Acute and subacute toxicity of copper sulfate pentahydrate $(\mathrm{CuSO}(4) 5 \cdot \mathrm{H}(2) \mathrm{O})$ in the guppy (Poecilia reticulata). J Vet Med Sci 71(3):333-336

Patra P, Mitra S, Debnath N, Goswami A (2012) Biochemical-, biophysical-, and microarray-based antifungal evaluation of the buffer-mediated synthesized nano zinc oxide: an in vivo and in vitro toxicity study. Langmuir 28(49):16966-16978

Pavlica S, Gaunitz F, Gebhardt R (2009) Comparative in vitro toxicity of seven zinc-salts towards neuronal PC12 cells. Toxicol In Vitro 23(4):653-659

Perreault F, Oukarroum A, Melegari SP, Matias WG, Popovic R (2012) Polymer coating of copper oxide nanoparticles increases nanoparticles uptake and toxicity in the green alga Chlamydomonas reinhardtii. Chemosphere 87(11):1388-1394

Piccinno F, Gottschalk F, Seeger S, Nowack B (2012) Industrial production quantities and uses of ten engineered nanomaterials for Europe and the world. J Nanopart Res 14:1109-1120

Piret JP, Jacques D, Audinot JN, Mejia J, Boilan E, Noël F, Fransolet M, Demazy C, Lucas S, Saout C, Toussaint O (2012a) Copper(II) oxide nanoparticles penetrate into HepG2 cells, exert cytotoxicity via oxidative stress and induce pro-inflammatory response. Nanoscale 4(22):7168-7184

Piret JP, Vankoningsloo S, Mejia J, Noël F, Boilan E, Lambinon F, Zouboulis, Masereel B, Lucas S, Saout C, Toussaint O (2012b) Differential toxicity of copper (II) oxide nanoparticles of similar hydrodynamic diameter on human differentiated intestinal Caco2 cell monolayers is correlated in part to copper release and shape. Nanotoxicology 6(7):789-803

Poynton HC, Lazorchak JM, Impellitteri CA, Smith ME, Rogers K, Patra M, Hammer KA, Allen HJ, Vulpe CD (2011) Differential gene expression in Daphnia magna suggests distinct modes of action and bioavailability for $\mathrm{ZnO}$ nanoparticles and $\mathrm{Zn}$ ions. Environ Sci Technol 45(2):762-768

Poynton HC, Lazorchak JM, Impellitteri CA, Blalock BJ, Rogers K, Allen HJ, Loguinov A, Heckman JL, Govindasmawy S (2012) Toxicogenomic responses of nanotoxicity in Daphnia magna exposed to silver nitrate and coated silver nanoparticles. Environ Sci Technol 46(11):6288-6296

Rallo R, Damoiseaux R, Telesca D, Mädler L, Cohen Y, Zink JI, Nel AE (2012) Use of metal oxide nanoparticle band gap to develop a predictive paradigm for oxidative stress and acute pulmonary inflammation. ACS Nano 6(5):4349-4368 
Ren X, Meng X, Chen D, Tang F, Jiao J (2005) Using silver nanoparticle to enhance current response of biosensor. Biosens Bioelectron 21(3):433-437

Research and Markets (2012) http://www.researchandmarkets.com/ reports/2116313/the_global_market_for_zinc_oxide_nanopow ders_2012.pdf

Ruparelia JP, Chatterjee AK, Duttagupta SP, Mukherji S (2008) Strain specificity in antimicrobial activity of silver and copper nanoparticles. Acta Biomater 4(3):707-716

Sanderson H, Johnson DJ, Wilson CJ, Brain RA, Solomon KR (2003) Probabilistic hazard assessment of environmentally occurring pharmaceuticals toxicity to fish, daphnids and algae by ECOSAR screening. Toxicol Lett 144(3):383-395

Sandstead HH (1995) Requirements and toxicity of essential trace elements, illustrated by zinc and copper. Am J Clin Nutr 61(3 Suppl):621S-624S

Sargent JF (2012) Nanotechnology: A Policy Primer. http://www.fas. org/sgp/crs/misc/RL34511.pdf

Sau TK, Rogach AL, Jäckel F, Klar TA, Feldmann J (2010) Properties and applications of colloidal nonspherical noble metal nanoparticles. Adv Mater 22(16):1805-1825

Schrurs F, Lison D (2012) Focusing the research efforts. Nat Nanotechnol 7:546-548

Seiffert JM, Baradez MO, Nischwitz V, Lekishvili T, GoenagaInfante H, Marshall D (2012) Dynamic monitoring of metal oxide nanoparticle toxicity by label free impedance sensing. Chem Res Toxicol 25(1):140-152

Serpone N, Dondi D, Albini A (2007) Inorganic and organic UV filters: their role and efficacy in sunscreens and suncare products. Inorg Chim Acta 360:794-802

Shakibaie MR, Harati A (2004) Metal accumulation in Pseudomonas aeruginosa occur in the form of nanoparticles on the cell surface. Iran J Biotech 2(1):55-60

Sharifi S, Behzadi S, Laurent S, Forrest ML, Stroeve P, Mahmoudi M (2012) Toxicity of nanomaterials. Chem Soc Rev 41(6):2323-2343

Shaw BJ, Al-Bairuty G, Handy RD (2012) Effects of waterborne copper nanoparticles and copper sulphate on rainbow trout (Oncorhynchus mykiss): physiology and accumulation. Aquat Toxicol 116-117:90-101

Shi JP, Ma CY, Xu B, Zhang HW, Yu CP (2012) Effect of light on toxicity of nanosilver to Tetrahymena pyriformis. Environ Toxicol Chem 31(7):1630-1638

Shvedova AA, Kagan VE, Fadeel B (2010) Close encounters of the small kind: adverse effects of man-made materials interfacing with the nano-cosmos of biological systems. Annu Rev Pharmacol Toxicol 50:63-88

Song W, Zhang J, Guo J, Zhang J, Ding F, Li L, Sun Z (2010) Role of the dissolved zinc ion and reactive oxygen species in cytotoxicity of ZnO nanoparticles. Toxicol Lett 199(3):389-397

Sovova T, Koci V, Kochankova L (2009) Ecotoxicity of nano and bulk forms of metal oxides. In: Proceedings, NANOCON Conference, Roznov pod Radhostem. Czech Republic, pp 62-71, 20-22 October 2009

Suresh AK, Pelletier DA, Wang W, Moon J-W, Gu B, Mortensen NP, Allison DP, Joy DC, Phelps TJ, Doktycz MJ (2010) Silver nanocrystallites: biofabrication using Shewanella oneidensis, and an evaluation of their comparative toxicity on gram-negative and gram-positive bacteria. Environ Sci Technol 44(13):5210-5215

Teitzel GM, Parsek MR (2003) Heavy metal resistance of biofilm and planktonic Pseudomonas aeruginosa. Appl Environ Microb 69(4):2313-2320

Teodorovic I, Planojevic I, Knezevic P, Radak S, Nemet I (2009) Sensitivity of bacterial vs. acute Daphnia magna toxicity tests to metals. Cent Eur J Biol 4(4):482-492

Unger C, Lück C (2012) Inhibitory effects of silver ions on Legionella pneumophila grown on agar, intracellular in Acanthamoeba castellanii and in artificial biofilms. J Appl Microbiol 112(6):1212-1219

Vargas-Reus MA, Memarzadeh K, Huang J, Ren GG, Allaker RP (2012) Antimicrobial activity of nanoparticulate metal oxides against peri-implantitis pathogens. Int $\mathrm{J}$ Antimicrob $\mathrm{Ag}$ 40(2):135-139

Wang WX, Guan R (2010) Subcellular distribution of zinc in Daphnia magna and implication for toxicity. Environ Toxicol Chem 29(8):1841-1848

Wang H, Wick RL, Xing B (2009) Toxicity of nanoparticulate and bulk $\mathrm{ZnO}, \mathrm{Al}_{2} \mathrm{O}_{3}$ and $\mathrm{TiO}_{2}$ to the nematode Caenorhabditis elegans. Environ Pollut 157(4):1171-1177

Wang Z, Chen J, Li X, Shao J, Peijnenburg WJ (2012a) Aquatic toxicity of nanosilver colloids to different trophic organisms: contributions of particles and free silver ion. Environ Toxicol Chem 31(10):2408-2413

Wang Z, Li N, Zhao J, White JC, Qu P, Xing B (2012b) CuO nanoparticle interaction with human epithelial cells: cellular uptake, location, export, and genotoxicity. Chem Res Toxicol 25(7):1512-1521

Wiench K, Wohlleben W, Hisgen V, Radke K, Salinas E, Zok S, Landsiedel R (2009) Acute and chronic effects of nano- and nonnano-scale $\mathrm{TiO}_{2}$ and $\mathrm{ZnO}$ particles on mobility and reproduction of the freshwater invertebrate Daphnia magna. Chemosphere 76(10):1356-1365

Wilson W (2012) Consumer products inventory Project on Emerging Nanotechnologies, a project of the Woodrow Wilson International Center for Scholars. http://www.nanotechproject.org

Wong SW, Leung PT, Djurisić AB, Leung KM (2010) Toxicities of nano zinc oxide to five marine organisms: influences of aggregate size and ion solubility. Anal Bioanal Chem 396(2):609-618

Wu Y, Zhou Q (2013) Silver nanoparticles cause oxidative damage and histological changes in medaka (Oryzias latipes) after 14 days of exposure. Environ Toxicol Chem 32(1):165-173

Wu J, Wang L, He J, Zhu C (2012) In vitro cytotoxicity of $\mathrm{Cu}^{2+}$, $\mathrm{Zn}^{2+}, \mathrm{Ag}^{+}$and their mixtures on primary human endometrial epithelial cells. Contraception 85(5):509-518

Xie Y, He Y, Irwin PL, Jin T, Shi X (2011) Antibacterial activity and mechanism of action of zinc oxide nanoparticles against Campylobacter jejuni. Appl Environ Microb 77(7):2325-2331

Xiong D, Fang T, Yu L, Sima X, Zhu W (2011) Effects of nano-scale $\mathrm{TiO}_{2}, \mathrm{ZnO}$ and their bulk counterparts on zebrafish: acute toxicity, oxidative stress and oxidative damage. Sci Total Environ 409(8):1444-1452

Xu M, Li J, Iwai H, Mei Q, Fujita D, Su H, Chen H, Hanagata N (2012) Formation of nano-bio-complex as nanomaterials dispersed in a biological solution for understanding nanobiological interactions. Sci Rep 2:406

Yang X, Gondikas AP, Marinakos SM, Auffan M, Liu J, Hsu-Kim H, Meyer JN (2012) Mechanism of silver nanoparticle toxicity is dependent on dissolved silver and surface coating in Caenorhabditis elegans. Environ Sci Technol 46(2):1119-1127

Yilmaz EI (2003) Metal tolerance and biosorption capacity of Bacillus circulans strain EB1. Res Microbiol 154(6):409-415

Yu LP, Fang T, Xiong DW, Zhu WT, Sima XF (2011) Comparative toxicity of nano- $\mathrm{ZnO}$ and bulk $\mathrm{ZnO}$ suspensions to zebrafish and the effects of sedimentation, $\mathrm{OH}$ production and particle dissolution in distilled water. J Environ Monit 13(7):1975-1982

Zhang L, Mu X, Fu J, Zhou Z (2007) In vitro cytotoxicity assay with selected chemicals using human cells to predict target-organ toxicity of liver and kidney. Toxicol In Vitro 21(4):734-740

Zhang H, Ji Z, Xia T, Meng H, Low-Kam C, Liu R, Pokhrel S, Lin S, Wang X, Liao YP, Wang M, Li L, Rallo R, Damoiseaux R, Telesca D, Mädler L, Cohen Y, Zink JI, Nel AE (2012a) Use of metal oxide nanoparticle band gap to develop a predictive 
paradigm for oxidative stress and acute pulmonary inflammation. ACS Nano 6(5):4349-4368

Zhang J, Song W, Guo J, Zhang J, Sun Z, Ding F, Gao M (2012b) Toxic effect of different $\mathrm{ZnO}$ particles on mouse alveolar macrophages. J Hazard Mater 219-220:148-155

Zhao CM, Wang WX (2012) Importance of surface coatings and soluble silver in silver nanoparticles toxicity to Daphnia magna. Nanotoxicology 4:361-370

Zhao Z, Sakagami Y, Osaka T (1998) Relationship between residual metal ions in a solution and the inhibitory capability of the metal ions for pathogenic bacterial growth. Bull Chem Soc Jpn 71:939-945

Zhao J, Wang Z, Liu X, Xie X, Zhang K, Xing B (2011) Distribution of $\mathrm{CuO}$ nanoparticles in juvenile carp (Cyprinus carpio) and their potential toxicity. J Hazard Mater 197:304-310
Zhao HZ, Lu GH, Xia J, Jin S (2012) Toxicity of Nanoscale CuO and ZnO to Daphnia magna. Chem Res Chin U 28(2):209-213

Zhu X, Zhu L, Duan Z, Qi R, Li Y, Lang Y (2008) Comparative toxicity of several metal oxide nanoparticle aqueous suspensions to Zebrafish (Danio rerio) early developmental stage. J Environ Sci Heal A 43(3):278-284

Zhu X, Zhu L, Yongsheng C, Tian S (2009) Acute toxicities of six manufactured nanomaterial suspensions to Daphnia magna. J Nanopart Res 11:67-75

Zook JM, Halter MD, Cleveland D, Long SE (2012) Disentangling the effects of polymer coatings on silver nanoparticle agglomeration, dissolution, and toxicity to determine mechanisms of nanotoxicity. J Nanopart Res 14:1165 